\title{
Established and Emerging Optical Technologies for the Real-Time Detection of Cervical Neoplasia: A Review
}

\author{
Breana Hill1,2, Sylvia F. Lam ${ }^{3}$, Pierre Lane ${ }^{3}$, Calum MacAulay3, Leonid Fradkin², \\ Michele Follen ${ }^{1,2,3^{*}}$ \\ ${ }^{1}$ New York Medical College, Valhalla, NY, USA \\ ${ }^{2}$ Department of Obstetrics and Gynecology, Brookdale Hospital and Medical Center, Brooklyn, NY, USA \\ ${ }^{3}$ The British Columbia Cancer Research Centre, Vancouver, BC, Canada \\ Email: *michelefollen@gmail.com
}

How to cite this paper: Hill, B., Lam, S.F., Lane, P., MacAulay, C., Fradkin, L. and Follen, M. (2017) Established and Emerging Optical Technologies for the Real-Time Detection of Cervical Neoplasia: A Review. Journal of Cancer Therapy, 8, 1241-1278 https://doi.org/10.4236/jct.2017.813105

Received: October 5, 2017

Accepted: December 18, 2017

Published: December 21, 2017

Copyright ( 2017 by authors and Scientific Research Publishing Inc. This work is licensed under the Creative Commons Attribution International License (CC BY 4.0).

http://creativecommons.org/licenses/by/4.0/

\begin{abstract}
Cervical cancer remains a critically important problem for women, especially those women in the developing world where the case-fatality rate is high. There are an estimated 528,000 cases and 266,000 deaths worldwide. Established screening and detection programs in the developed world have lowered the mortality from $40 / 100,000$ to $2 / 100,000$ over the last 60 years. The standard of care has been and continues to be: a screening Papanicolaou smear with or without Human Papilloma Virus (HPV) testing; followed by colposcopy and biopsies and if the smear is abnormal; and followed by treatment if the biopsies show high grade disease (cervical intraepithelial neoplasia (CIN) grades 2 and 3 and Carcinoma-in-situ). Low grade lesions (Pap smears with Atypical Cells of Uncertain Significance (ASCUS), Low Grade Squamous Intraepithelial Lesions (LGSIL), biopsies showing HPV changes or showing CIN 1); are usually followed for two years and then treated if persistent. Treatment can be performed with loop excision, LASER, or cryotherapy. Loop excision yields a specimen which can be reviewed to establish the diagnosis more accurately. LASER vaporizes the lesion and cryotherapy leads to tissue destruction. Under long term study; loop excision, LASER, and cryotherapy have the same rate of cure. The standard of care is expensive and takes 6 - 12 weeks for the individual patient. During the last twenty years, new technologies that can view the cervix and even image the cervix with cellular resolution have been developed. These technologies could lead to a new paradigm in which diagnosis and treatment occurs at a single visit. These technologies include fluorescence and reflectance spectroscopy (probe or wide-field, whole cervix scanning approaches) and fluorescence confocal endomicroscopy or high resolution micro-endoscopy. Both technologies have received Federal Drug Administration (FDA) and have been commer-
\end{abstract}


cialized. Research trials continue to show their remarkable performance. These technologies are reviewed and clinical trials are summarized. Emerging technologies are coming along that may compete with those already approved and include optical coherence tomography, optical coherence tomography with autofluorescence, diffuse optical microscopy, and dual mode micro-endoscopy. These technologies are also reviewed and where available, clinical data is reported. Optical technologies are ready to diffuse into clinical practice because they will save money and 3 or 4 visits in the developed world and offer the same standard of care to the developing world where more cervical cancer exists.

\section{Keywords}

Cervical Cancer Detection, Cervical Cancer Screening, Cervical Cancer Diagnosis, Optical Technologies, Real-Time Diagnosis

\section{Introduction}

Cervical cancer is the fourth most common cancer among women worldwide, with 528,000 new diagnoses and 266,000 deaths per year as estimated in 2012 by the World Health Organization [1]. Incidence and stage at diagnosis depend on the extent of utilization of screening programs, as evidenced by the disparate proportion of advanced disease in developing nations [2]. As an example, in Nigeria, advanced-stage disease at presentation is common ( $86 \%$ to $89.3 \%$ of new cases), while in the UK only $21.9 \%$ of women present with Stage II + disease [3]. With early detection, death from cervical cancer is preventable, and 5-year survival of Stage I cancers is approximately 92\%. Despite the advantage of screening, such programs present a tremendous economic burden to society. According to Insigna et al., it is estimated that the annual cost of cervical HPV-related disease amounted to $\$ 3.4$ billion in the US in 1998. A significant portion of this (\$300 million) was spent on "treating" false-positive findings on Papanicolaou smears [4]. In the developing world, where fiscal burden remains a limitation to screening, it would be preferential to obtain more effective means of diagnosis and treatment (ideally simultaneously) that would decrease not only the wait time associated with diagnosis, but also the overall number of health care visits required to treat precancerous lesions of the cervix. Real-time, more affordable devices are being developed, in hopes of detecting cervical cancer in its preinvasive stages more readily. This article seeks to give a comprehensive review of the various means of optical imaging technologies developed for the early detection of cervical cancer.

\section{Current Screening and Detection Programs for Cervical Neoplasia}

Organized screening programs in high-resource settings have been based on the 
use of the Papanicolaou smear, a cytologic sampling of the cervix. Papanicolaou smears are routinely begun at age 21 , and carried on every 3 years until age 30 . At age 30, the patient can opt to receive concurrent HPV testing with the Pap smear and receive testing every 5 years until age 65 [5] [6] [7]. If at any point the Pap smear is abnormal, a second visit is required for a colposcopy in which the cervix is visualized under 3.5 to 15 -fold magnification. Typically, acetic acid at $5 \%$ to $6 \%$ concentration is used as a contrast agent, and the cervix is viewed using white and green light. The green light enhances the recognition of abnormal vasculature. Colposcopically-directed biopsies are then performed. After biopsies are read by a pathologist, the patient returns for a third visit for any necessary treatment [6]. The Papanicolaou smear was the subject of a meta-analysis by Fahey that used raw data and reported the sensitivity to be $61 \%$ and specificity to be $65 \%$. Guillaud reported using tripled reviewed histopathology and the sensitivity for the detection of high grade disease was $44 \%$ and specificity $96 \%$. It should be noted that the trial on which he reported were smears obtained before optical imaging and may have been performed more gently to avoid disrupting the imaging. Mitchell in a meta-analysis reported the Papanicoloau smear has a sensitivity of $\sim 60 \%$ and a specificity of $90 \%$. This low sensitivity but high specificity mean those that are referred to colposcopy most often have disease (90\%) but also many with disease are missed $(100 \%-60 \%=40 \%)$. Colposcopy, on the other hand, has a high sensitivity $\sim 95 \%$ but a low specificity of $50 \%$ meaning some biopsies appear abnormal but are negative histopathologically when reviewed [8] [9]. Here we see colposcopy overcalls at the expense of specificity (up to $50 \%$ of the time biopsies may not show high-grade) but usually doesn't miss a lesion (correct $95 \%$ of the time). Together, they work quite well and both incidence and mortality from cervical cancer have consistently decreased seven-fold over the last 40 years.

Visual inspection with acetic acid (VIA) is a simpler screening methodology. It involves the application of acetic acid to the cervix, followed by visual examination of tissue with the naked eye and under white-light illumination for aceto-whitening. VIA is used in developing countries due to its low cost, which results from the use of inexpensive reagents, minimal equipment, and the ability to "see-and-treat" patients at that visit. Sankarananayanan reported on large and robust trials in India comparing Pap, HPV testing, and VIA. Over two publications he reports the sensitivity and specificity of: the Papaniclaou smear in 22,663 patients as $58 \%$ and $95 \%$, HPV testing in 18,085 patients as $67 \%$ and $94 \%$, and VIA in 54,981 patients as $77 \%$ and $86 \%$. Because aceto-whitening requires intact cells, invasive cancers may not bind acetic acid. In those lesions, it is more valuable to observe the surface morphology, the vasculature, and/or the tendency to bleed. Unfortunately, inflammation can often appear very abnormal. More effective approaches are needed to detect cervical cancer in resource-poor settings [10] [11] [12] [13] [14].

In discussion of cervical cancer screening, it is important to note the basis for additional Human Papilloma Virus (HPV) testing. The HPV test is extremely sen- 
sitive with sensitivities of $95+\%$ and specificities also high at $90+\%$ [15]. HPV testing is an excellent adjunct test to the Papanicolaou smear and may someday replace it. HPV infection is the major risk factor for cervical cancers, especially with the high-risk strains HPV 16, 18, 31, 33, 35, 39, 45, 51, 52, 56, 58, 59 and 68. Although the vaccine against high-risk HPV strains became routine in 2006, it is approximated that only about a third of teenage girls in the US have been fully vaccinated as of 2013 [16]. The vaccines have proven effective, however, as the prevalence of vaccine-type strains of HPV has decreased from $11.5 \%$ to $5.1 \%$ in females aged 9 - 14, a decrease of 56\% [16]. The effectiveness of the HPV vaccine remains limited by accessibility, cost, and willingness of parents to allow their children to partake in the vaccine schedule.

Due to the high prevalence rate in women under 30, HPV testing remains a valuable tool for early detection of cervical neoplasia in adults over the age of 30 . Researchers found several weaknesses with cytology (Papanicolaou smear) alone: results are dependent on the high quality of the sample being collected; the test requires subjective interpretation of morphological changes within cells, and the prevalence of false negatives. HPV DNA is present in almost all cervical cancers, the tests are readily available and easily performed, and have been found to demonstrate higher sensitivity for high grade CIN (CIN2+) than that achieved by cytology (96.1\% vs. 53.0\%) [17]. These tests are limited in being used as the primary screening method for cervical cancer because of the lack of specificity. Many patients are identified with infections but both the Papanicolaou smear sampling at colposcopy is negative. Furthermore, because of the high prevalence of HPV DNA before age 30, HPV co-testing is not recommended for women ages 21 to 29. Over the age of 30, past the peak of HPV infections, HPV testing has a higher positive predictive value.

Another limitation of HPV testing, especially in developing countries, is its cost. According to Mandelblatt et al., the Pap smear costs a mere $\$ 10$ for the laboratory fee compared to an HPV test at an average laboratory fee of $\$ 30$ for the hybrid capture II or $\$ 77$ for PCR [18]. One must also understand that a positive HPV test requires a second visit for either a repeat Pap smear or further diagnosis with colposcopy. Many patients are identified that are HPV positive but their Papanicolaou smear and colposcopically-directed biopsies are negative. The aims of optical technology are to reduce these costs and to provide the patient with a diagnosis and treatment in the same visit.

Figure 1 shows the current paradigm for the standard of care and a suggested alternative using the established and emerging technologies in this review.

There are three important and predictable changes in tissue that form the foundation for the use of real-time, automated optical technologies. These are changes in cell turnover affecting the biochemistry of the tissue, the development of abnormal blood vessels to fuel growth, and changes in nucleus of the cells that reflects abnormal duplication and growth. These three changes form the biological basis for the adoption of optical technologies. Fluorescence spectroscopy measures the biochemical changes in tissue. Reflectance spectroscopy 

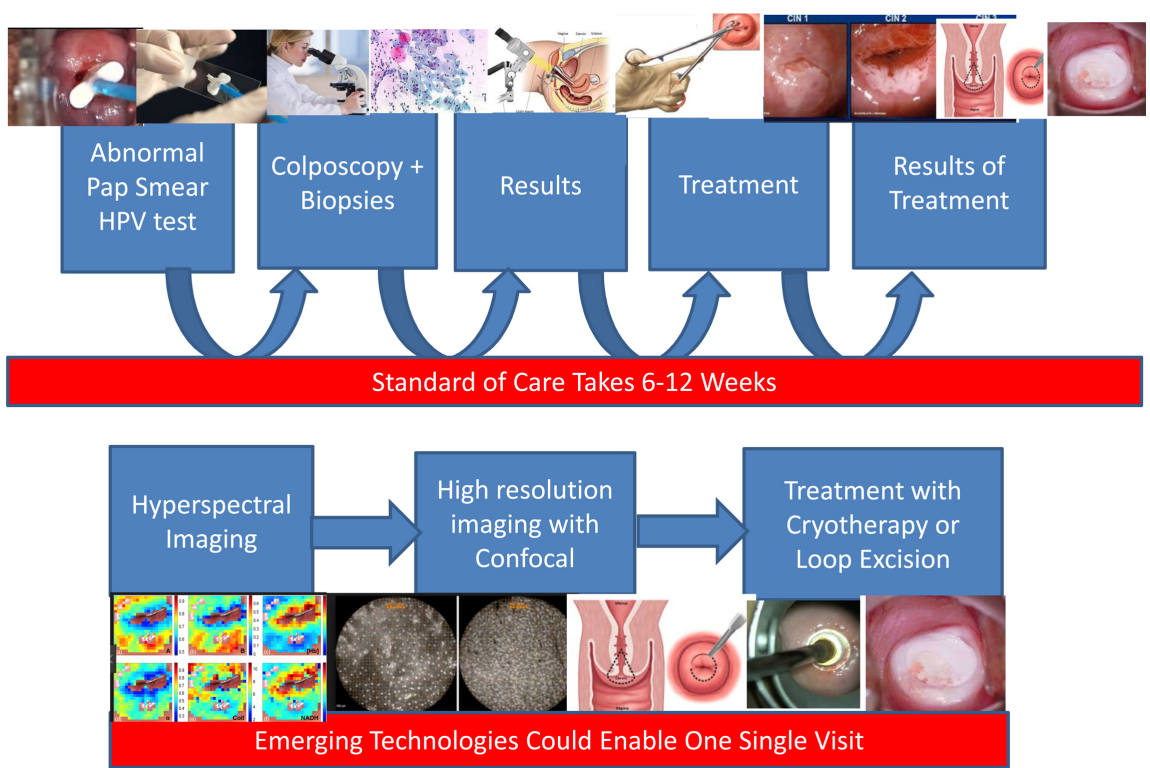

Figure 1. Current standard of care versus possible new path with FDA approved technologies.

visualizes the changes in chromatin in the cells. Confocal Micro-endoscopy has the resolution to detect cell nuclei. These three changes form the basis for the biological basis for the adoption on new technologies. Table 1 shows endoscope-compatible optical technologies and their role in cancer screening and detection in all organ sites [19].

We know that as intraepithelial neoplasia develops, it secretes growth factors that increase the vasculature to supply nutrients to the lesion. The nuclear-tocytoplasmic ratio increases within cells as less cytoplasm is produced and the amount of DNA within the nucleus increases. Additionally, the stroma underlying

Table 1. Established optical technologies for cancer detection.

\begin{tabular}{|c|c|c|c|c|}
\hline Modality & Biological Measure & Resolution & Cost in US\$ & Clinical Development \\
\hline $\begin{array}{l}\text { White light } \\
\text { endoscopy }\end{array}$ & $\begin{array}{l}\text { Surface Morphology } \\
\text { and Vasculature }\end{array}$ & $1 \mathrm{~mm}$ & $4-13,000$ & Standard of Care \\
\hline $\begin{array}{l}\text { Fluorescence } \\
\text { and Reflectance } \\
\text { Spectroscopy }\end{array}$ & $\begin{array}{l}\text { Redox Ratio, } \\
\text { Collagen and Elastin } \\
\text { Remodelling }\end{array}$ & $1 \mathrm{~mm}$ & 30,000 & $\begin{array}{l}\text { Additive to Oral Exam, } \\
\text { Bronchoscopy, } \\
\text { Esophagoscopy, } \\
\text { Colonoscopy }\end{array}$ \\
\hline $\begin{array}{c}\text { Narrow } \\
\text { Band Imaging }\end{array}$ & Neovascularization & $1 \mathrm{~mm}$ & 13,000 & $\begin{array}{l}\text { Additive to } \\
\text { Colonoscopy }\end{array}$ \\
\hline $\begin{array}{c}\text { Optical Coherence } \\
\text { Tomography }\end{array}$ & $\begin{array}{c}\text { Mucosal Stratification } \\
\text { and Subsurface Tissue } \\
\text { Morphology }\end{array}$ & $\begin{array}{l}5-15 \\
\text { microns }\end{array}$ & $40-100,000$ & $\begin{array}{l}\text { Clinical Approved in } \\
\text { Ophthalmology, } \\
\text { Clinical Trials in } \\
\text { Other Organ Sites }\end{array}$ \\
\hline $\begin{array}{c}\text { Confocal } \\
\text { Endomicroscopy }\end{array}$ & $\begin{array}{l}\text { Subsurface Tissue and } \\
\text { Cell Morphology }\end{array}$ & 1 micron & 70,000 & $\begin{array}{l}\text { Being Evaluated in } \\
\text { Multiple Organ Sites }\end{array}$ \\
\hline
\end{tabular}


even preinvasive lesions can show an influx of inflammatory cells as well as changes in collagen type, collagen cross-linking and elastin modifications to prepare for further growth of the lesion. Advances in magnification and resolution could increase the sensitivity of the endoscope by allowing clinicians to see microvasculature and surface changes in epithelium. With this foundation, we can begin to understand the utility of optical technologies in cancer detection. Table 2 shows the subjects of this review that pertain to the cervical detection [20]-[105].

\section{Methods}

We searched PubMed and Google scholar from 2007 to 2017 for: fluorescence spectroscopy and screening/detection of cervical neoplasia, and human trials; reflectance spectroscopy and screening/detection of cervical neoplasia, and human trials; fluorescence and reflectance spectroscopy, screening/detection of cervical neoplasia, and human trials; confocal endomicroscopy, fluorescence confocal endomicroscopy, and high resolution Micro Endoscopy, screening/detection of cervical neoplasia, and human trials; optical coherence tomography and screening/detection of cervical neoplasia, and human trials; diffuse optical microscopy and screening/detection of cervical neoplasia, and human trials; and dual mode endomicroscopy and screening/detection of cervical neoplasia, and human

Table 2. Established and emerging technologies for the detection of cervical neoplasia.

\begin{tabular}{|c|c|c|c|}
\hline Modality & $\begin{array}{l}\text { Biological } \\
\text { Measure }\end{array}$ & Resolution & $\begin{array}{c}\text { Clinical } \\
\text { Development }\end{array}$ \\
\hline \multicolumn{4}{|l|}{ Established Technologies } \\
\hline $\begin{array}{l}\text { Colposcopy } \\
\text { Using White and } \\
\text { Green/Blue Light }\end{array}$ & $\begin{array}{c}\text { Surface Morphology } \\
\text { and Vasculature }\end{array}$ & $1 \mathrm{~mm}$ & Standard of Care \\
\hline Multispectral IMAGING & $\begin{array}{l}\text { Cell Turnover and } \\
\text { Elastin/Collagen } \\
\text { Remodelling }\end{array}$ & $1 \mathrm{~mm}$ & $\begin{array}{c}\text { LUMA and DYsis } \\
\text { (FDA Approved) and } \\
\text { LuViva (Undergoing } \\
\text { FDA Approval) }\end{array}$ \\
\hline $\begin{array}{l}\text { Confocal Endomicroscopy } \\
\text { or High Resolution } \\
\text { Micro Endoscopy }\end{array}$ & $\begin{array}{c}\text { Cellluar } \\
\text { Architecture }\end{array}$ & 1 micron & $\begin{array}{c}\text { Mauna Kea } \\
\text { Cellvizio } \\
\text { (FDA Approved) }\end{array}$ \\
\hline \multicolumn{4}{|l|}{ Emerging Technologies } \\
\hline $\begin{array}{c}\text { Optical Coherence } \\
\text { Tomography }\end{array}$ & $\begin{array}{l}\text { Mucosa and } \\
\text { Stroma }\end{array}$ & $\begin{array}{l}5-15 \\
\text { microns }\end{array}$ & Research \\
\hline $\begin{array}{l}\text { Diffuse Optical } \\
\text { Microscopy }\end{array}$ & $\begin{array}{c}\text { Depth Resolved } \\
\text { Cellular Architecture }\end{array}$ & 1 micron & Research \\
\hline $\begin{array}{c}\text { Dual Mode } \\
\text { Endomicroscopy }\end{array}$ & $\begin{array}{c}\text { Depth Resolved } \\
\text { Cellular Architecture }\end{array}$ & 1 micron & Research \\
\hline
\end{tabular}


trials; Google Scholar brought up over 5000 articles in these searches. We reviewed the first 1000; 762 were rejected, 20 could not be obtained, and 218 were cited (of those rejected: 296 other organ site, 56 patents, 75 review articles, 3 case reports, 31 tissue/blood studies, 5 animal studies, 145 other technologies, 53 phantom studies or instrumentation only, 41 contrast agents, and 57 photodynamic therapy). We rejected articles that were studies of cells or animal studies and those performed on in vitro specimens only without a human trial. We rejected patents, instrumentation papers, and probe design articles. We rejected case studies of one patient. We rejected articles from other organ sites: head and neck, gastrointestinal tract, pancreas, brain, bladder, ovary, and skin. The remainder of the rejections were clinical trials in humans of the cervix, but were not the technologies of interest for this review. We excluded Raman spectroscopy, electric impedance, vibrational spectroscopy, photoacoustic devices, digital time-delayed colposcopy, infrared spectroscopy, and photodynamic technologies. We have performed extensive reviews of fluorescence and reflectance and other optical technologies in 2003, 2005, and 2007.

\section{Overview of the Established Devices}

Some technologies, like colposcopy, have been used since 1940. The big advance in its use was the addition of acetic acid as a contrast agent. Multispectral imaging devices were/are still being tested and several have been commercialized and have/waiting for Federal Drug Administration (FDA) approval. Confocal endomicroscopy (also called fluorescence confocal endomicroscopy and high resolution microendoscopy) has/is being studied and one company has received FDA approval and commercialized its use in other organ sites. Richards-Kortum et al. have designed a device of this kind that fits in a briefcase and can be used in the resource-poor setting globally [20]-[108].

\subsection{Colposcopy}

The colposcopy is a mounted microscope that can enlarge the cervix from 3.5 to 15 fold. White light is used before and after the placement of acetic acid. Acetic acid binds to the DNA in the cellular nucleus in keratinized cells. The blue or green light is used to make vessels more prominent. As vascular abnormalities progress with the advancement of dysplastic lesions to neoplastic lesions, the vessels are an important part of the exam. The vessels have been found to change in predictable formations as lesions advance to cancer. The cervix is made up of two parts: the ectocervix and endocervix. Either can harbor a cancer. Colposcopically-directed biopsies are taken of the ectocervix as well as a sampling of the endocervical canal. Treatment can be decided after these results are obtained. It should be noted that entire process of obtaining a Papanicolaou smear, its reading, the return visit at which the patient may or may not undergo colposcopy, the colposcopy, the histopathological review, the treatment, and a follow up visit take 6 - 8 weeks in the US and Canada [109] [110]. 


\subsection{Fluorescence and Reflectance Spectroscopy}

\subsubsection{Probe}

Fluorescence spectroscopy is one of the most widely used techniques for studying the structure and function of macromolecules in biology and chemistry. Fluorescence reveals ligand-induced conformational changes in proteins and subtle environmental changes of chromophores. When the sample is autofluoresced, there is an excitation of intrinsic fluorophores that causes these molecules to emit their photons on return to ground state. It has been reported that an increase in $\mathrm{NADH}$ fluorescence and a decrease in collagen fluorescence provide clinically significant differences between normal and dysplastic tissues and could be used as quantitative fluorescence biomarkers for in vivo detection of dysplasia. That spectral output is analyzed using an algorithm and can report the likelihood of high grade dysplasia [111]-[133].

\subsubsection{Multi-Spectral Digital Colposcopy}

The multispectral digital colposcope views the cervix in its entirety. Multispectral imaging systems are a modification of the standard colposcope with a video camera adapter that measures reflectance and fluorescence images of the cervix using a color video camera. With two-dimensional imaging, the entire surface of the cervix, including the endocervix, can be visualized, possibly reducing the chance of sampling error. Figure 2 shows commercialized devices and their interface with the cervix and/or output [134]-[171].

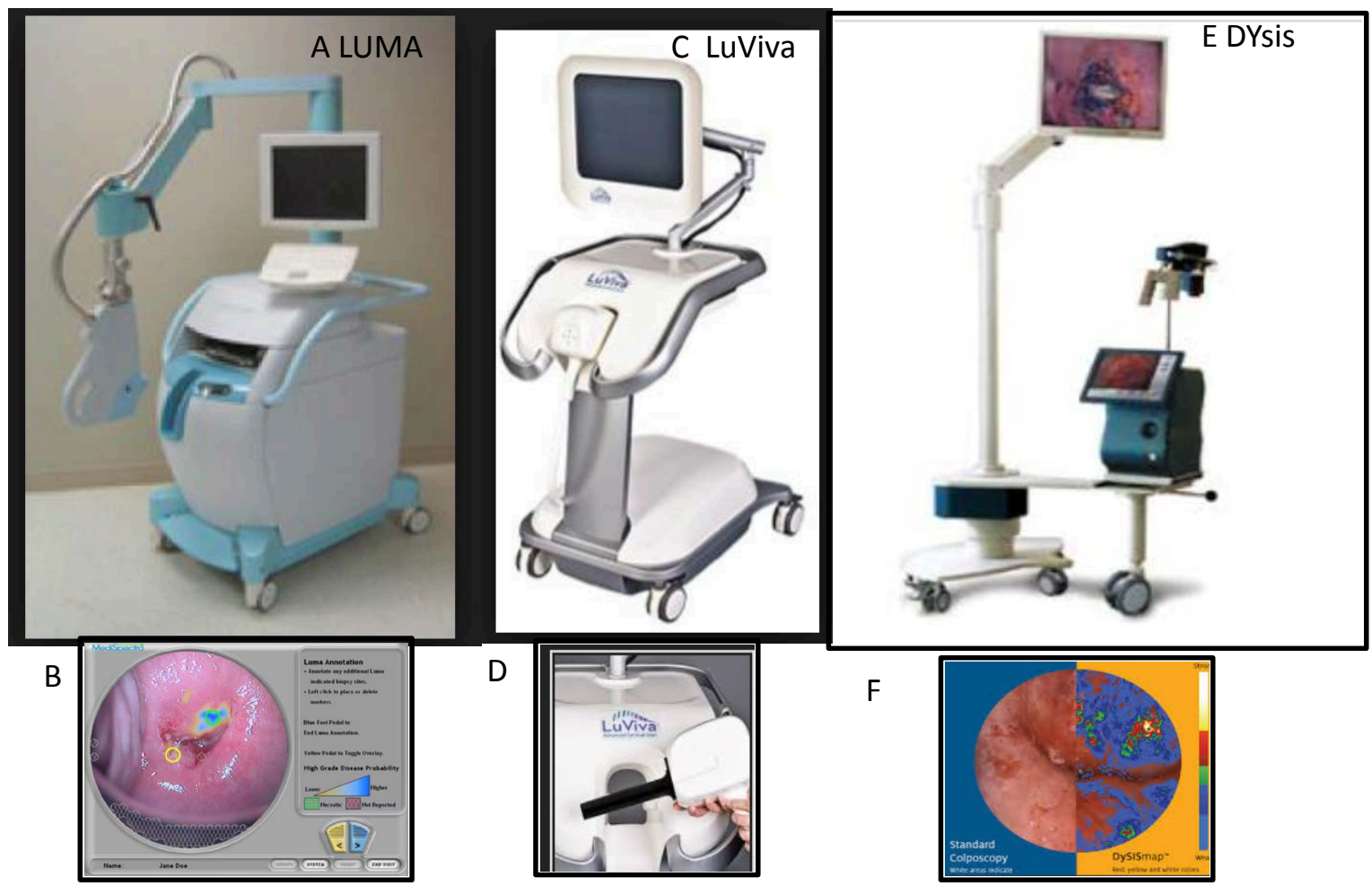

Figure 2. (A) LUMA device; (B) View from LUMA to clinician; (C) LuViva device; (D) Interface of LuViva with the cervix; (E) Dysis device; (F) Cervical digitized images ready for automated analysis in real-time. 


\subsubsection{Confocal Endomicroscopy, Fluorescence Confocal Endomicroscopy, and High Resolution Micro Endoscopy}

Fluorescence confocal endomicroscopy can provide clinicians with the ability to assess tissue grade by generating real-time cellular-level images of morphological features, providing the patient with immediate diagnosis and treatment options simultaneously. Figure 3 shows a research grade confocal endomicroscopy device and its output.

In fluorescence microscopy, exogenous DNA-staining fluorophore molecules (acriflavine hydrochloride used in the study by Schlosser et al.) are topically administered onto the cervical mucosa. Fluorescent light is emitted from these fluorophores and because a dichroic mirror is added to the set-up, efficient separation of excitation and emission light is achieved, producing a high-quality image. Imaging depth is limited to about $50 \mu \mathrm{m}$ due to the finite permeation of the applied fluorophore dye.

Acriflavine temporarily intercalates nucleic acids, accumulating predominantly in the nucleus and the fluorescent light passes through the dichroic beam splitter and detection pinhole. This scanned fluorescence emission is captured by an avalanche photodiode. A frame grabber amplifies and digitizes this detected light and generates images by use of synchronization signals from the resonant scanner. The imaging device is built into a handheld wand, which is controlled using custom software that allows for changing the focal depth, recording video and images, basic image corrections, and contrast enhancement. Figure 4 and Figure 5 show how well the device mimics histopathologic sections [172]-[191].

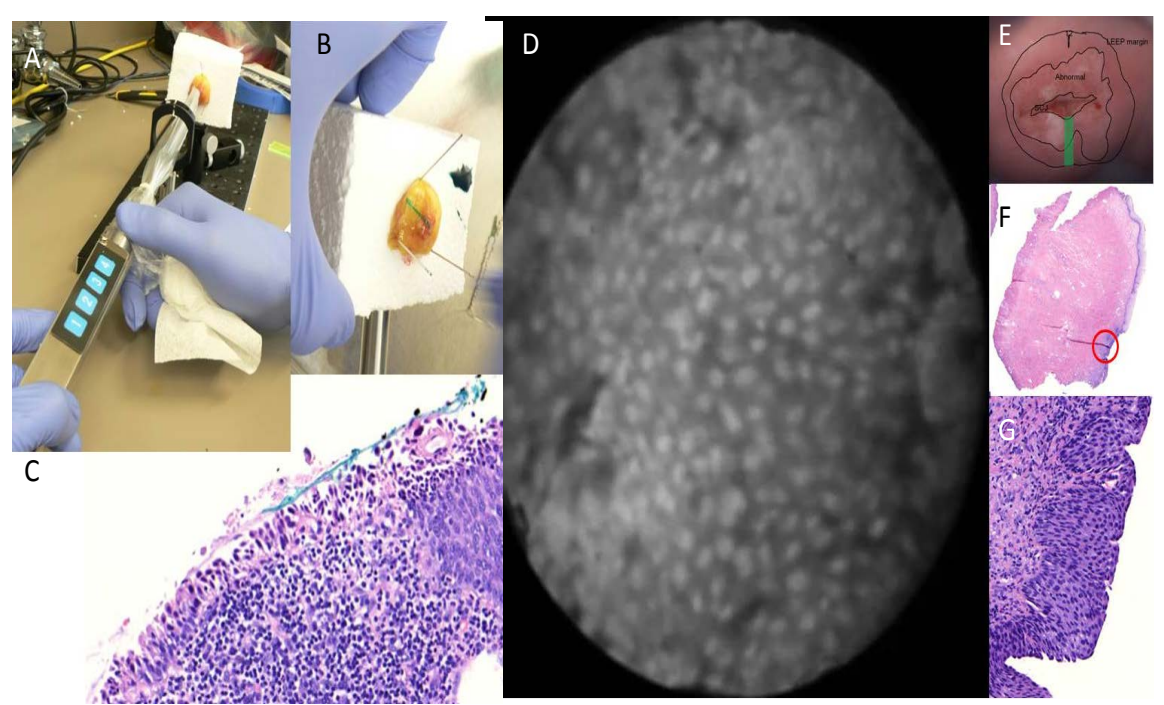

Figure 3. The confocal endomicroscopy device showing the setup for (A) Measurement of the cervical specimen taken by loop excision; (B) Excised and inked cervical specimen mounted for measurement; (C) Inked section of high grade dysplasia histopathologic marked in (B) and in (E); (D) Screenshot image of inked section taken with the confocal endomicroscopy device; (E) Cervix in situ in patient before excision; (F) Section of tissue under low power; and (G) Another view of tissue section showing carcinoma-in-situ under high power. 


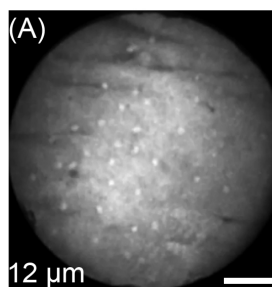

(E)

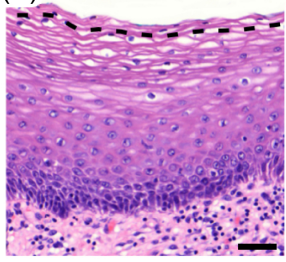

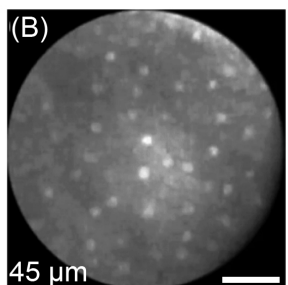

(F)

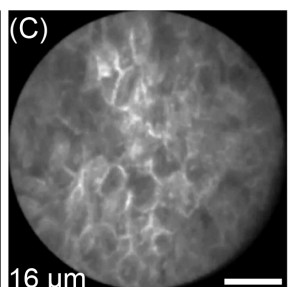

(G)

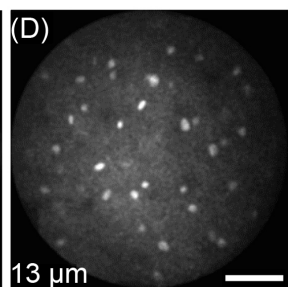

(H)

Figure 4. Normal squamous epithelium as imaged by the confocal endomicroscopy device (A)-(D) along with co-registered histological sections (E)-(H). Scale bars measure $50 \mu \mathrm{m}$. Dashed lines indicate the corresponding imaging depth as quantified in (A)-(D). Image (C) and section $(\mathrm{G})$ depict glycogen rich epithelium. Image (D) was captured in vivo.

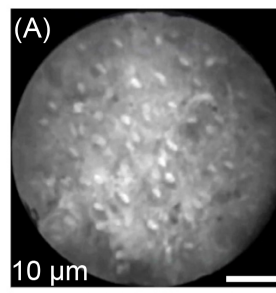

(E)

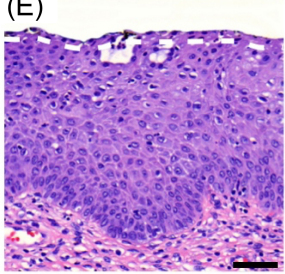

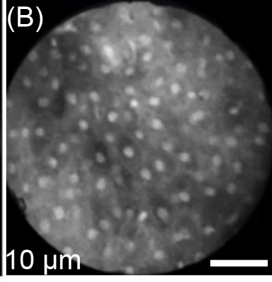

(F)

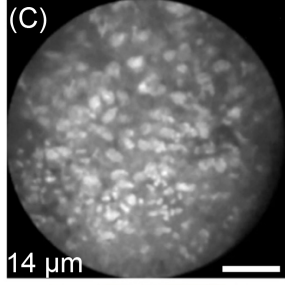

(G)

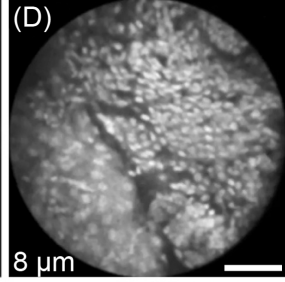

( $\mathrm{H})$

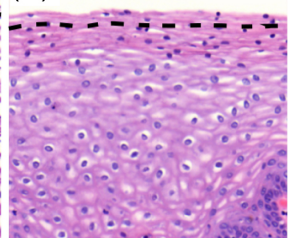

Figure 5. Confocal endomicroscopy of high grade squamous intra-epithelial lesions as captured as captured at superficial depths (A)-(D) and stained histology sections (E)-(H) corresponding to the same imaging locations. Scale bars measure $50 \mu \mathrm{m}$. (A) (B) (E) (F) is classified as CIN 2, while (C) (D) (G) (H) contain CIN 3 tissue.

\section{Overview of Emerging Technologies}

\subsection{Optical Coherence Tomography (OCT) with or without Autofluorescence Imaging (AFI)}

OCT provides high-resolution structural information from below the tissue surface. Analogous to ultrasound but with higher resolution and lower penetration, it allows the clinician to visualize and quantify the thickness of epithelia and detect micro invasion through the basement membrane.

Some investigators are combining the measurement of autofluorescence imaging (AFI) with OCT which shows the functional contrast of structural proteins, and enables visualization of vascular networks, fibrosis, and nodules. It has been used clinically for the early detection of lung and oral cancer and has shown potential in multi-center trials for the detection of cervical cancer. Figure 6 shows 

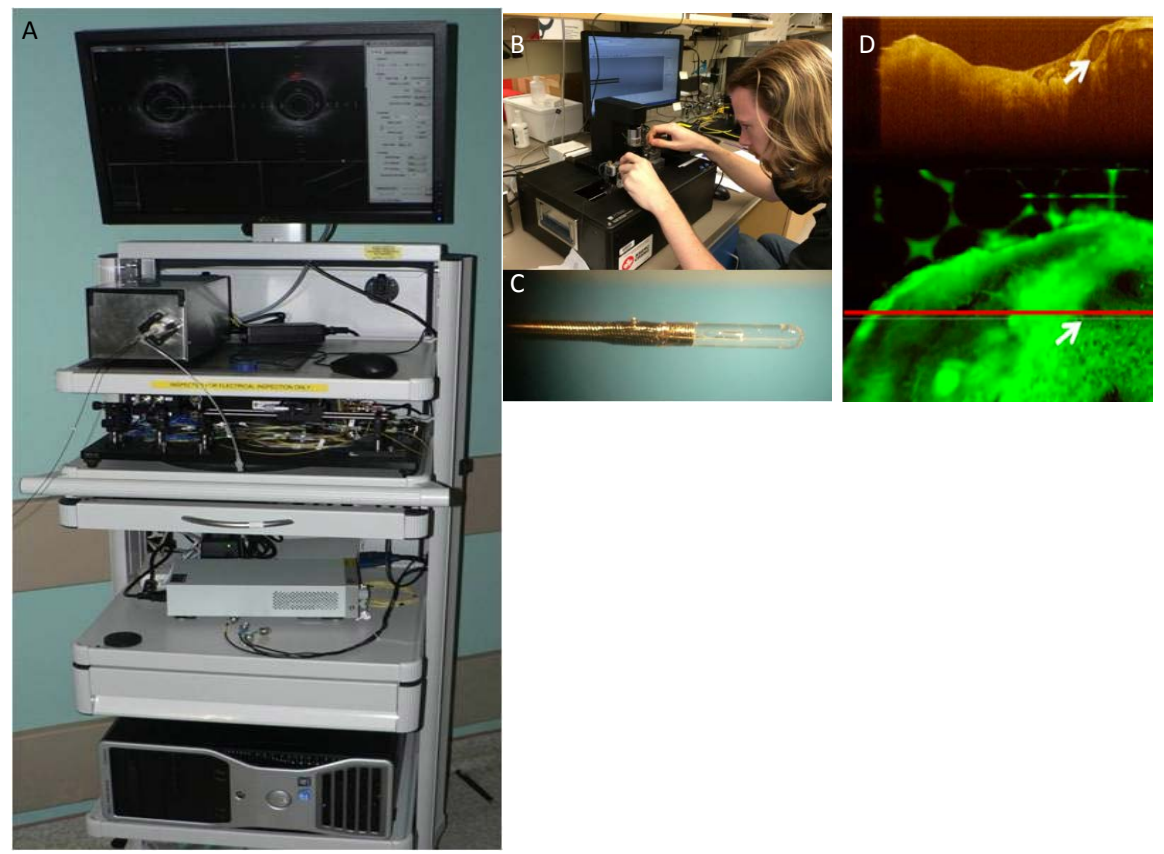

Figure 6. Optical coherence tomography with auto-fluorescence (A) Device; (B) Post-doctoral fellow working on device; (C) Photo of catheter tip; and (D) Co-registered OCT-AF image of a freshly excised cervical loop specimen imaged using the bench-top instrument featured in image.

a bench-top OCT device with autofluorescence [192]-[205].

\subsection{Diffuse Optical Microscopy (DOM)}

Another way of measuring tissue microstructure is to study the tissue's lightscattering properties. Experimental studies suggest that the microscopic and submicroscopic refractive index variations within the cell are the dominant sources of cellular scattering. Owing to the high optical density of the nucleus, cellular light backscattering is mostly influenced by the size of the nucleus and its chromatin texture, allowing detection of dysplasia or cancer-related morphological changes through quantification of tissue light backscattering. In DOM, multiple laterally structured sinusoidal projection patterns are employed to quantify tissue light backscattering. Figure 7 shows the DOM [206].

\subsection{Dual Mode Endomicroscopy (DME)}

This imaging modality combines fluorescence endomicroscopy (FE) with diffuse optical microscopy (DOM). Combining these two modalities affords complementary sensitivity to the structural changes found in precancerous development. FE images nuclear structure of superficial epithelial cell layers by using a nuclei-staining extrinsic fluorophore dye that reveals dysplasia via increased nuclear size and density. The use of FE alone, however, is limited by its inability to detect moderate dysplasia where structural changes are limited to deeper cell layers. Figure 8 shows the device and images. When FE is combined with DOM, we gain the ability to 


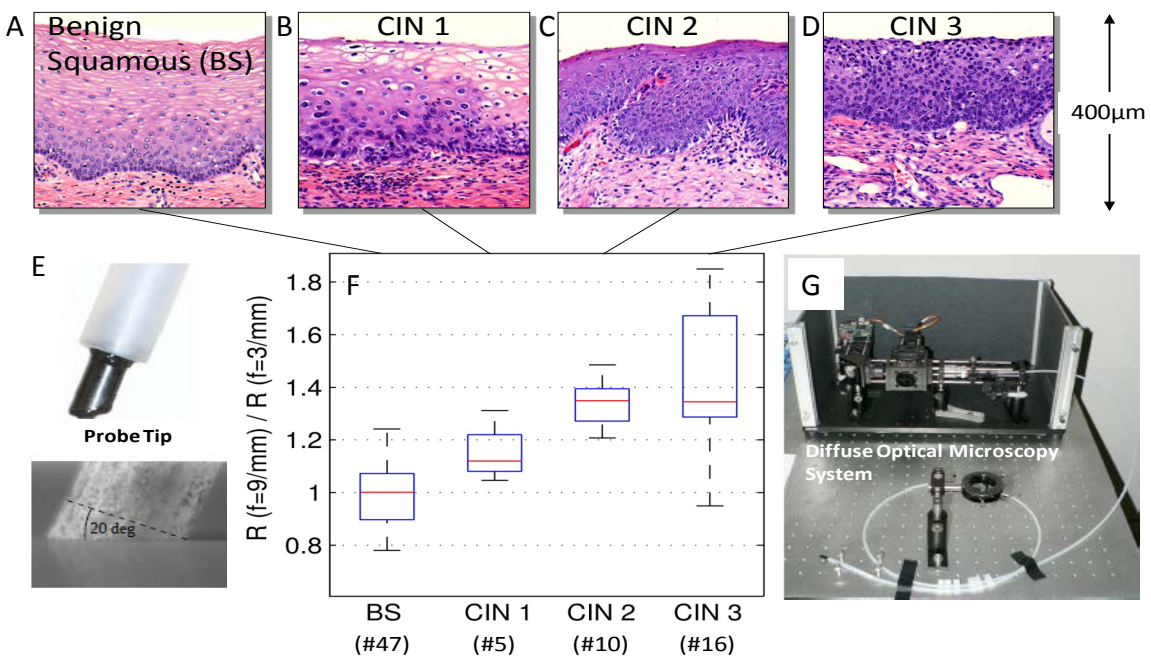

Figure 7. The diffuse optical microscopy device (DOM). Cervical tissue showing (A) benign normal epithelium; (B) Cervical intraepithelial neoplasia (CIN) grade 1; (C) CIN 2; and (D) CIN 3; (E) DOM probe top; (F) Graph showing comparison of measurements from tissue by diagnosis; and (G) Actual diffuse optical microscopy device used for this study.

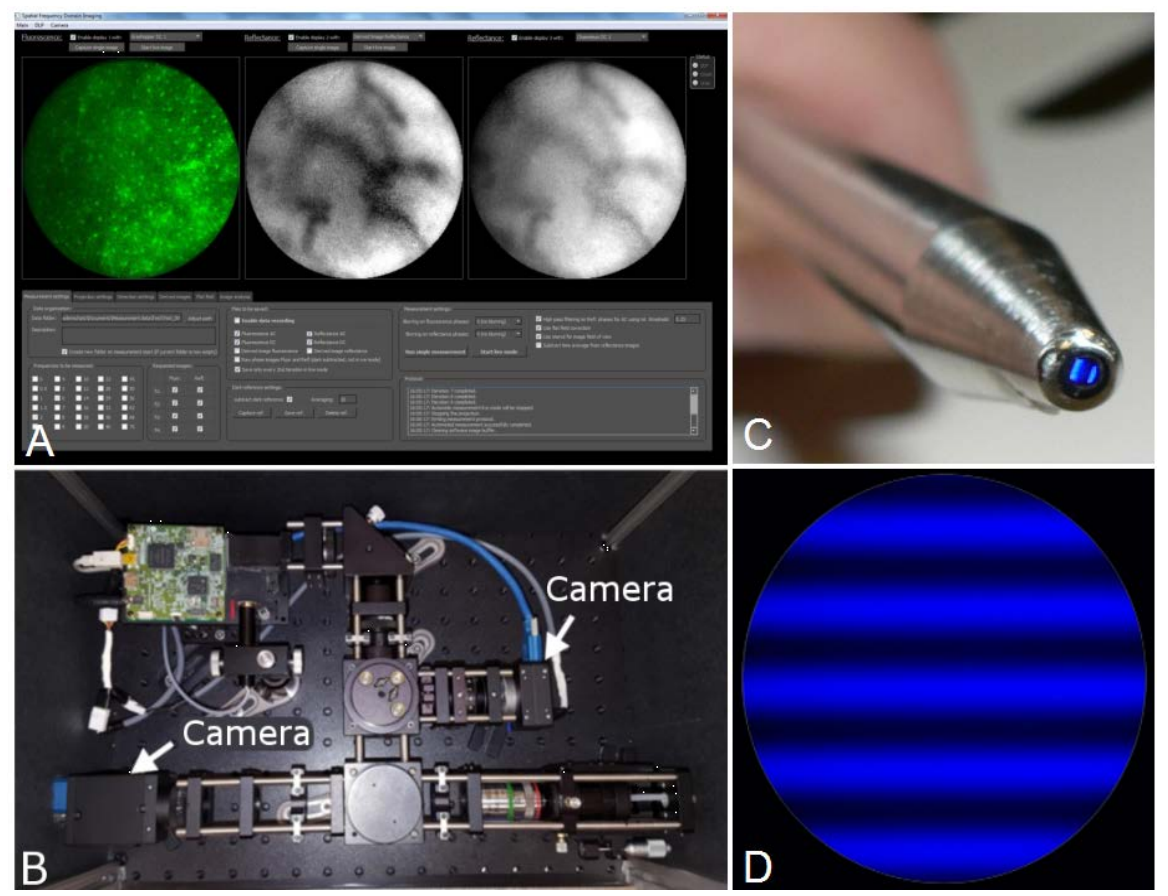

Figure 8. (A) The clinical dual mode endomicroscopy system software interface; (B) The optical setup; (C) A close up of the imaging probe containing the fiber bundle for light projection and detection; (D) A close up of a structured light pattern emanating from the tip of the probe.

penetrate tissue to diagnostically meaningful depths within the epithelium. DOM has been described above.

With DME, blue excitation light encounters three major interaction processes relevant to the device: fluorescence, backscattering, and absorption. Acriflavine 
hydrochloride is topically applied to the tissue surface and fluoresces with a spectrum centered around wavelength of $500 \mathrm{~nm}$. In the setup, wavelengths above $460 \mathrm{~nm}$ are transmitted through a dichroic mirror and focused onto a digital camera. A second portion of the light is backscattered while retaining wavelength, and if directed back into the optical setup, it is partly guided to a second digital camera. Light absorption by intrinsic tissue molecules is the third interaction process which affects DOM, with hemoglobin being the dominant absorber at the 445-nm excitation wavelength being used. This allows for observation of vascular patterns in the images [207].

\section{Results of Pilot Studies, Clinical Trials, and Randomized Clinical Trials for Established Technologies}

Table 3 summarizes the trials reported in this review by author, trial design, number of patients, sensitivities and specificities. Pilot studies are unplanned observational trials without a calculated sample size that explore the technology in the desired population. Clinical trials are planned and statistically justified trials that account for confounders. Randomized clinical trials are planned experiments that balance confounders in both arms through the randomization process. Sensitivities and specificities can be reported by patient or by site in the case of a probe study. In our analyses of our own trials, the per patient and per site analyses did not differ. If both were provided the report in the table is a per patient sensitivity and specificity. If per patient was not provided, we reported the per site number.

\subsection{Colposcopy}

Mitchell et al. performed a meta-analysis of colposcopy in 1998 and included the largest clinical trials in which patients were referred for abnormal Papanicolaou smears and who presented raw data that could be analyzed. The studies were published in English but came from around the world from recognized coloposcopists. There were 5378 patients for whom raw data was available. The study included the calculation of sensitivities, specificities, positive and negative predictive values, likelihood ratios, and area under the Receiver Operating Curve. In consideration of separating high-grade disease from all other, the weighted sensitivity of colposcopy was $96 \%$ and the weighted specificity was $48 \%$.

The ASCUS/LSIL Triage Study for Cervical Cancer (ALTS) trial reported sensitivities for the trial but not specificities. The sensitivity of colposcopy in the Immediate Colposcopy Group was 54\% and in the Standard of Care Group with a preceding abnormal Papanicolaou smear was 55\%. In subsequent publications, they found the sensitivity varied by the number of cervical biopsies with $68 \%$ for one biopsy, $82 \%$ for two biopsies, and $83 \%$ for three biopsies. There were many study sites with different levels of attendings and residents participating. The findings differ from the meta-analyses mentioned earlier. Those may suffer from publication bias as those that publish are probably more interested in colposcopy 
Table 3. Clinical studies of established and emerging technologies for cervical detection.

\begin{tabular}{lcc}
\hline Clinical Innestigator Year Threshold & $\begin{array}{c}\text { Number of } \\
\text { Patients }\end{array}$ Sensitivity Specificity \\
\hline Trial Design
\end{tabular}

Fluorescence Spectroscopy

Probe

$\begin{array}{cccccc}\text { Pilot } & \text { Ramanujam 1994 } & \text { SIL } & 28 & 87 & 73 \\ \text { Pilot } & \text { Ramanujam 1996 } & \text { SIL } & 64 & 91 & 76 \\ \text { Pilot } & \text { Ramanujam 1996 } & \text { SIL } & 92 & 88 & 70 \\ \text { Pilot } & \text { Mitchell 1999 } & \text { SIL } & 92 & 88 & 70 \\ \text { Pilot } & \text { Mitchell 1999 } & \text { SIL } & 54 & 76 & 81 \\ \text { Pilot } & \text { Weingandt 2002 } & \text { HG } & 68 & 88 & 53 \\ \text { Clinical Trial } & \text { Belinson 2001 } & \text { HG } & 1997 & 94 & 9 \\ \text { Clinical Trial } & \text { Chang 2002 } & \text { HG } & 146 & 71 & 70\end{array}$

Multispectral

$\begin{array}{cccccc}\text { Pilot } & \text { Wright 1999 } & \text { SIL } & 19 & 99 & 95 \\ \text { Pilot } & \begin{array}{c}\text { Dattamajurndar } \\ \text { 2001 }\end{array} & \text { SIL } & 52 & 84 & 93 \\ \text { Pilot } & \text { Parker 2000 } & \text { HG } & 35 & 80 & 81 \\ \text { Pilot } & \text { Parker 2002 } & \text { LG } & 17 & 98 & 99\end{array}$

Reflectance Spectroscopy

Probe

$\begin{array}{cccccc}\text { Clinical Trial } & \text { Coppleson 1994 } & \text { HG } & 163 & 90 & 90 \\ \text { Clinical Trial } & \text { Mirabal 2002 } & \text { HG } & 161 & 72 & 83 \\ \text { Clinical Trial } & \text { Singer 2003 } & \text { HG } & 651 & 70 & 77 \\ \text { Pilot } & \text { Mourant 2007 } & \text { HG } & 36 & 100 & 80\end{array}$

Multispectral

$\begin{array}{cccccc}\text { Clinical Trial } & \text { Orfaoudaki 2005 } & \text { SIL } & 134 & 91 & 100 \\ \text { Clinical Trial } & \text { Soutter 2009 } & \text { HG } & 296 & 53 & 86 \\ \text { Clinical Trial } & \text { Louwers 2010 } & \text { HG } & 239 & 65 & 70 \\ \text { Clinical Trial } & \text { Zaal 2012 } & \text { HG } & 177 & 80 & 77 \\ \text { Pilot } & \text { Prabitha 2014 } & \text { HG } & 41 & 100 & 100 \\ \text { Clinical Trial } & \text { Coronado 2016 } & \text { HG } & 150 & 88 & 86 \\ \text { Clinical Trial } & \text { DeNardis 2017 } & \text { HG } & 365 & 75 & 47\end{array}$

Combined Fluorescence and Reflectance Spectroscopy

Probe

\begin{tabular}{|c|c|c|c|c|c|}
\hline Pilot & Geogeakoudi 2005 & SIL & 44 & 92 & 71 \\
\hline Clinical Trial & Chang 2005 & HG & 161 & 83 & 80 \\
\hline Clinical Trial & Cantor 2010 & HG & 1850 & 100 & 71 \\
\hline Clinical Trial & Yamal 2012 & HG & 1850 & 98 & 62 \\
\hline Clinical Trial & $\begin{array}{c}\text { NCT01094132 } \\
2018\end{array}$ & HG & 552 & Pending & Pending \\
\hline
\end{tabular}




\section{Continued}

Multispectral

\begin{tabular}{|c|c|c|c|c|c|}
\hline Pilot & Burke 1996 & SIL & 36 & 96 & 71 \\
\hline Pilot & Burke 1999 & SIL & 46 & 93 & 94 \\
\hline Pilot & Burke 1999 & SIL & 36 & 89 & 93 \\
\hline Clinical Trial & Nordstrom 2001 & SIL & 41 & 82 & 67 \\
\hline Clinical Trial & Nordstrom 2001 & SIL & 41 & 91 & 93 \\
\hline Clinical Trial & Ferris 2001 & $\mathrm{HG}$ & 111 & 95 & 83 \\
\hline Clinical Trial & Desantis 2003 & HG & 572 & 83 & 80 \\
\hline Pilot & Benevides 2003 & $\mathrm{HG}$ & 29 & 82 & 68 \\
\hline Clinical Trial & Huh 2004 & HG & 604 & 92 & 50 \\
\hline Pilot & Milbourne 2005 & $\mathrm{HG}$ & 46 & 80 & 70 \\
\hline Clinical Trial & Werner 2007 & HG & 113 & 95 & 66 \\
\hline \multirow[t]{2}{*}{$\begin{array}{l}\text { Randomized } \\
\text { Clinical Trial }\end{array}$} & Alvarez 2007 & HG & Colpo only 55 & 53 & 89 \\
\hline & & & $\begin{array}{c}\text { Colpo+ } \\
\text { device } 56\end{array}$ & 52 & 90 \\
\hline Pilot & Park 2007 & HG & 29 & 79 & 88 \\
\hline Clinical Trial & Twiggs 2013 & $\mathrm{HG}$ & 1607 & 91 & 39 \\
\hline Clinical Trial & $\begin{array}{c}\text { NCT01094132 } \\
2018\end{array}$ & HG & 552 & Pending & Pending \\
\hline Clinical Trial & $\begin{array}{c}\text { NCT00602368 } \\
2018\end{array}$ & HG & 219 & Pending & Pending \\
\hline
\end{tabular}

Confocal Microendoscopy or High Resolution Microendoscopy

$\begin{array}{cccccc}\text { Pilot } & \text { Tan } & \text { HG } & 25 & 97 & 93 \\ \text { Pilot } & \text { Quinn } & \text { HG } & 26 & 86 & 87 \\ \text { Pilot } & \text { Pierce 2012 } & \text { HG } & 63 & 100 & 67 \\ \text { Clinical Trial } & \text { NCT02574442 } & \text { HG } & \text { pending } & \text { pending } & \text { pending } \\ \text { Clinical Trial } & \text { NCT02420665 } & \text { HG } & \text { pending } & \text { pending } & \text { pending }\end{array}$

Optical Coherence Tomography

$\begin{array}{lccccc}\text { Clinical Trial } & \text { Escobar 2006 } & \text { HG } & 212 & 56 & 59 \\ \text { Clinical Trial } & \text { Wulan 2010 } & \text { HG } & 183 & 61 & 80 \\ \text { Clinical Trial } & \text { Liu 2010 } & \text { HG } & 299 & 24 & 96 \\ \text { Clinical Trial } & \text { Gallwas 2010 } & \text { HG } & 60 & 95 & 46 \\ \text { Clinical Trial } & \text { Gallwas 2011 } & \text { HG } & 120 & 64 & 60 \\ \text { Clinical Trial } & \text { Kang 2011 } & \text { HG } & 74 & 51 & 92 \\ \text { Clinical Trial } & \text { NCT02272075 } & \text { HG } & \text { pending } & \text { pending } & \text { pending } \\ \text { Clinical Trial } & \text { NCT01766284 } & \text { HG } & \text { pending } & \text { pending } & \text { pending }\end{array}$

and usually have many years of clinical experience. The ALTS trial was trying to look at what happened in the real world, not in centers that specialized in colposcopy. 
Cantor et al. reported on a phase II trial in which 1000 screening patients and 850 diagnostic patients with abnormal Papanicolaou smears underwent colposcopy and colposcopically directed biopsies along with fluorescence and reflectance spectroscopy. The sensitivity of colposcopy for the diagnosis of high grade was $98 \%$ and the specificity was $45 \%$ in the diagnostic population. Colposcopy in the screening population, in which there were few high-grade lesions, showed a sensitivity of $29 \%$ and the specificity was $88 \%$. Most diagnostic tests perform poorly when the prevalence of disease is low [109] [110].

\subsection{Fluorescence and Reflectance Spectroscopy}

\subsubsection{Probe}

Probe-based fluorescence and reflectance spectroscopy has been studied by 30 investigators, some with industrial funding and others with peer-reviewed funding from the National Institutes of Health. The potential for use of fluorescence spectroscopy in cervical cancer diagnosis has been investigated extensively. Cardenas-Turanzas, Freeberg, and Freeberg have performed extensive reviews and have examined many aspects of the trials designs that were used and the endpoints of interest. The largest trial which was reported by Cantor and colleagues showed a sensitivity of $100 \%$ and a specificity of $71 \%$. In this single study the large data set was divided into training, validation, and testing sets. The code was not broken on the test set until the algorithm was optimized on the training set. The algorithm in this analysis included colposocopic impression. In another analysis when colposcopic impression was eliminated in the algorithm, the sensitivity was $98 \%$ and specificity $62 \%$. This study showed that point probe fluorescence and reflectance spectroscopy could be additive to colposcopy by increasing the specificity. That group planned a randomized trial comparing colposcopy to spectroscopy but the study didn't accrue and had to be closed [111]-[133].

Across all studies, the fluorescence intensity of precancerous lesions is lower than normal squamous tissues, and peak emission wavelength of precancers is shifted to longer emission wavelengths relative to normal tissue (attributed to increased hemoglobin absorption and increased mitochondrial fluorescence in precancers). The performance, however, of optical algorithms is limited by the challenge of discriminating precancers at the junction between squamous and columnar epithelium, where cervical cancers frequently develop. Despite the good performance of this modality, it has not been commercialized.

\subsubsection{Multispectral Digital Colposcopy (MDC) Using Fluorescence and Reflectance Spectroscopy}

Benavides, Park and Milbourne have all reported on research-grade MDCs and across all three studies the sensitivity and specificity for the diagnosis of high grade is $\sim 80 \%$ and $\sim 80 \%$. More important to the commercialization, however, are the trials conducted by Medispectra Inc. and by SpectraRx Inc. now Guided Therapeutics. In 2007 SpectraRx bought Medispectra.

SpectraRx published several trials that were clinical trials with calculated sam- 
ple sizes. Desantis reported on 648 patients with sensitivities of $95 \%$ and specificities of $55 \%$ for the diagnosis of high grade. Twiggs reported on the same trial with more patients (1607) accrued and reported a sensitivity for the diagnosis of high grade as $91 \%$ and a specificity of $39 \%$. The LuViva device is undergoing FDA approval.

The strongest study is a randomized clinical trial. One has been conducted and reported by Alvarez. The trial evaluated colposcopy versus colposcopy plus the Medispectra LUMA device. The device in the trial showed a sensitivity for the diagnosis of high grade of $56 \%$ and a specificity for the diagnosis of High Grade of $87 \%$ while for colposcopy the sensitivity was $55 \%$ and the specificity was $85 \%$. The device was not additive but was the same as their colposcopy. While the device did not perform with their previously reported high sensitivities (91\%, 92\%), their colposcopy performance differs from that in the literature. If their colposcopy performance had a sensitivity of $95 \%$ then the additional specificity provided by the device would be additive and helpful to decrease unnecessary biopsies [134]-[171]. The LUMA device was approved by the FDA.

\subsubsection{Fluorescence Confocal Endomicroscopy}

High-resolution techniques such as the confocal can show tissue changes in epithelial cell morphology and architecture without the need for biopsy. Video-rate reflectance confocal microscopy yields images of intact epithelial tissue with $1-2$ micron spatial resolution and with acetic acid, can determine the nuclear to cytoplasmic ratio. Collier showed that the Nuclear to Cytoplasmic (N:C) ratio measured by confocal microscopy could be used to separate high-grade cervical precancers with a sensitivity and specificity greater than $90 \%$.

Confocal endomicroscopy provides high resolution imaging of tissue. Thekkek and Richards-Kortum describe an overview of optical technologies and describe the use of a portable confocal endomicroscopy, appropriate for the developing world in 2008. Cervical confocal microscopy has the potential to provide clinicians with real-time cellular-level images, allowing it to be used as an adjunct to colposcopic examination in facilitating proper biopsy-site selection. The clinical benefit of the tool could be greatly enhanced if its use could be extended from biopsy guidance to an independent tool for instant and accurate diagnosis. Furthermore, although it was limited in reliably differentiating all four tissue categories, additional use of Lugol's iodine to demarcate squamous and columnar epithelium could make it possible to reach an unambiguous diagnosis of HSIL in a majority of cases.

Schlosser et al. investigated fluorescence confocal endomicroscopy and its ability to differentiate variability between four cervical tissue types: normal columnar, normal and precancerous squamous epithelium, and stromal tissue. Figure 4 and Figure 5 represent the endomicroscopy and histological results of normal squamous epithelium and high-grade squamous intraepithelial lesions respectively. The high nuclear density of the latter clearly distinguishes the precancerous lesions from the normal epithelium. However, the limitation was in the observers' ability to dis- 
tinguish HSIL from normal columnar; $38 \%$ of the 150 cases associated with the HSIL group had all five observers selecting either "HSIL" or "normal columnar" as their diagnosis.

Schlosser describes the challenges, like those of endogenous fluorescence or with tissue type delineation, will arise with in vivo pathology and these will need to be overcome in the future. Confocal endomicroscopy yields videos and stacks at different depths. In a pilot trial ex vivo, 60 patients with high grade yielded 500 videos and 352 stacks. While the high grade disease was easily seen, the columnar epithelium appeared abnormal when it wasn't. The addition of contrast or combinations with other techniques with increases in penetration depth may add further value to cervical endomicroscopy [172]-[191].

\section{Results of Bench Studies, Pilot Studies, and Clinical Trials for Emerging Technologies}

\subsection{Optical Coherence Tomography (OCT)}

There are seven published works on OCT in the cervix. Fujimoto described technology and its potential. Zuluaga presented a pilot study and Escobar recruited 50 patients and studied attenuation but did not report sensitivities and specificities.

Wulan and Escobar each reported the use of OCT following the Visual Imaging with Acetic Acid. We acknowledge this is a potential use of the technology that could place it in resource poor settings. This makes the study preselected in a way that is different from those studies in which the only entry is an abnormal Papanicolaou smear.

Liu reported on a large trial in China. There were 1237 participants but this report focuses on the first 299 women for the whom the sensitivity of OCT for the diagnosis of high grade was $24 \%$ and the specificity was $96 \%$. Gallwas has two reports, the first from 2010 and the second from 2011. In the first she reports on 60 patients and the sensitivity for the diagnosis of high grade was $95 \%$ and the specificity $46 \%$. In the second trial, she reports on 120 women and found that the sensitivity for the diagnosis of high grade was $64 \%$ with a specificity of $60 \%$. This is not unusual in the early reporting of a technology.

Future improvements in resolution and the development of new light sources and optics may improve the specificity as well as differentiation of cervical dysplasia. OCT is also being studied for practical use in other gynecologic cancers, including those of the ovaries and fallopian tubes. Our group is combing OCT with autofluorescence imaging [192]-[205].

\subsection{Diffuse Optical Microscopy (DOM)}

Bodenschatz et al. demonstrated that reflectance intensities increase with the progression from benign squamous toward high-grade dysplasia at frequencies of 9 $\mathrm{mm}^{-1}$ and $15 \mathrm{~mm}^{-1}$. The increase in high-frequency reflectance for HSIL is expected due to the low cellular differentiation and high N:C ratio. They also noted that the addition of acetic acid amplified backscattering by $>70 \%$ for spatial fre- 
quencies of 9 and $15 \mathrm{~mm}^{-1}$. In contrast to common endomicroscopic modalities that rely on maximized resolution, DOM makes use of microscopic information encoded in backscattering signals to visualize dysplasia.

The pilot study performed by Bodenschatz et al. suggests that backscattering can be quantified using structured illumination. He studied 18 cervical specimens in which the entire cervical specimen was intact and was measured 30 - 90 minutes after excision. The tissue was processed normal and sectioned and read by a gynecologic pathologist. Sensitivities and specificities were not reported.

Low overall costs of the optical setup may make the system ideal for developing countries with the highest incidence of cervical cancer. Also, given its imaging speed and potential for a much larger field of view, DOM may be well suited for large-area tissues screening or for the assessment of resection and tumor margins.

However, the heterogeneity of the cervical epithelium presents a challenge in interpretation of imaging data. Larger imaging fields of views enabled by a wider image guide or a potential noncontact colposcopic or endoscopic implementation may help with the overall differentiation. Image quality may also be improved in the future with enhanced suppression of internal specular reflections using a microscope objective designed for epi-illumination as well as a camera with higher dynamic range. Further studies are needed to confirm the sensitivity of DOM to high nuclear density in cancer [206].

\subsection{Dual Mode Endomicroscopy (DME)}

We have developed a technology that will soon move to clinical trials in the cervix. Bodenschatz's pilot study with the Dual Mode Endomicroscopy on cervical lesions indicates a strong shift in depth-dependent epithelial backscattering related to the development of cervical precancer. Given the relatively low cost of the DME system, the hope is that after more comprehensive patient studies and acquisition of data, the DME can be used for biopsy guidance and in vivo diagnosis, and possibly also for tumor margin assessment.

Bodenschatz et al. conducted a pilot study on 21 patients with oral premalignant lesions or squamous cell carcinoma. The dual mode endomicroscopy was used to capture imaging data from known high-risk anatomical sites of the oral cavity, including the lateral tongue, ventral tongue and floor of the mouth. The team observed reflectance images to appear more heterogeneous in comparison to corresponding images of normal epithelium. In more than 50 percent of measured sites, nuclei were not visible in fluorescence, likely attributed to enhanced tissue fluorescence from surface keratin. However, they did reveal a significant increase in depth-dependent epithelial backscattering for almost all imaged dysplastic tissue with a biopsy-confirmed diagnosis; there is an increasing backscattering ratio when the degree of pathology increases. The study was too small to make any conclusions about the sensitivity and specificity values for dual mode endomicroscopy in the oral cavity, but it does demonstrate complementary contrast of two imaging modalities with the anticipation that it will give a high diagnostic yield. 
Schlosser et al. investigated fluorescence confocal endomicroscopy and its ability to differentiate variability between four cervical tissue types: normal columnar, normal and precancerous squamous epithelium, and stromal tissue. Figure 4 and Figure 5 below represent the endomicroscopy and histological results of normal squamous epithelium and high-grade squamous intraepithelial lesions respectively. The high nuclear density of the latter clearly distinguishes the precancerous lesions from the normal epithelium. However, the limitation was in the observers' ability to distinguish HSIL from normal columnar; $38 \%$ of the 150 cases associated with the HSIL group had all five observers selecting either "HSIL" or "normal columnar" as their diagnosis [207].

\section{Conclusions}

Here we report on established and emerging technologies relevant to cervical detection. Note that the standard of care paradigm takes not only $6-12$ weeks in the US and Canada but also the full treatment of high grade disease including loop excision pathology bills for $\sim \$ 5000$. The emerging technology arm could be performed in one visit and would cost $\sim \$ 2000$.

It may be hard to make the case for change in the developed world. Rogers writes eloquently about diffusion of technologies and the average length for diffusion is 17 years. It has been 18 years since fluorescence and reflectance spectroscopy probe data showed promise, 14 years since multi/hyperspectral colposcopy was successfully reported, and 10 years since a hyperspectral imaging device was FDA approved. It has been 14 years since confocal microendoscopy was reported and 9 since Richards-Kortum put it in a briefcase for the developing world. It's harder to make the case not to use technology in the developing world where resources are not available. We should be ready for translation of both technologies which complement each other nicely in both parts of the world.

OCT has promise and is in clinical trials. OCT has good tissue information but lacks biochemical information. OCT may have more promise if combined measurements of autofluorescence are included. The DOM could complement confocal microendoscopy in the future and maybe less expensive than the current systems under use. Whether it can be placed in a briefcase is left to be seen.

Our hope is that the more established technologies be used and that the emerging ones be tested in large trials to examine clinical effectiveness. Once demonstrated to be effective, they can be scaled to work without electricity in places where cervical cancer runs rampant.

In summary, real-time technologies have the capacity to change screening and diagnosis considerably. The use of these technologies has already been shown to be cost-effective. The impact will be greater, and may extend to the developing world, as the technologies become less expensive to build and simpler to implement [208]-[216].

\section{Funding}

NIH NCI P01CA 082710. 


\section{References}

[1] http://globocan.iarc.fr/Pages/fact_sheets_cancer.aspx

[2] Cantor, S.B., Atkinson, E.N., Cardenas-Turanzas, M., Benedet, J.L., Follen, M. and MacAulay, C. (2005) Natural History of Cervical Intraepithelial Neoplasia: A Meta-Analysis. Acta Cytologica, 49, 405-415. https://doi.org/10.1159/000326174

[3] Eleje, G., Eke, A., Igberase, G., Igwegbe, A. and Eleje, L. (2015) Palliative Interventions for Controlling Vaginal Bleeding in Advanced Cervical Cancer. Cochrane Database of Systematic Reviews, 2015, Article ID: CD011000. https://doi.org/10.1002/14651858.CD011000.pub2

[4] Insigna, R., Glass, A. and Rush, B. (2004) The Health Care Costs of Cervical Human Papillomavirus-Related Disease. American Journal of Obstetrics \& Gynecology, 191, 114-120. https://doi.org/10.1016/j.ajog.2004.01.042

[5] US Preventive Services Task Force (2017) Final Recommendation Statement. Cervical Cancer: Screening. https://www.uspreventiveservicestaskforce.org/BrowseRec/Index

[6] Wentzensen, N., Massad, L.S., Mayeaux, E.J., Khan, M.J., Waxman, A. and Huh, W.J. (2017) Evidence-Based Consensus Recommendations for Colposcopy Practice for Cervical Cancer Prevention in the United States. Journal of Lower Genital Tract Disease, 21, 216-222. https://doi.org/10.1097/LGT.0000000000000322

[7] Fahey, M.T., Irwig, L. and Macaskill, P. (1995) Meta-Analysis of Pap Test Accuracy. International Journal of Epidemiology, 141, 680-689. https://doi.org/10.1093/oxfordjournals.aje.a117485

[8] Cardenas-Turanzas, M., Follen, M., Nogueras-Gonzalez, G.M., Benedet, J.L., Beck, J.R. and Cantor, S.B. (2008) The Accuracy of the Papanicolaou Smear in the Screening and Diagnostic Settings. Journal of Lower Genital Tract Disease, 12, 269-275. https://doi.org/10.1097/LGT.0b013e31816b44bc

[9] Cardenas-Turanas, M., Nogueras-Gonzalez, G.M., Scheurer, M.E., Adler-Storthz, K., Benedet, J.L., Beck, J.R., Follen, M. and Cantor, S.B. (2008) The Performance of Human Papillomavirus High-Risk DNA in the Screening and Diagnostic Settings. Cancer Epidemiology Biomarkers \& Prevention, 17, 2865-2871. https://doi.org/10.1158/1055-9965.EPI-08-0137

[10] http://who.int/reproductivehealth/publications/cancers/9789241503860/en/

[11] Sankaranarayanan, R., Basu, P., Wesley, E.S., Mahe, C., Keita, N. and Mbalawa, C.C. (2004) Accuracy of Visual Screening for Cervical Neoplasia Results from an IARC Multicenter Study in India and Africa. International Journal of Cancer, 110, 907-913. https://doi.org/10.1002/ijc.20190

[12] IARC Screening Group (2017) Accuracy of Screening Tests. http://screening.iarc.fr/study.acc.php

[13] Li, M., Shi, J.F., Franceschi, S., Zhang, W.-H., Dai, M., Liu, B., Zhang, Y.-Z., Li, L.-K., Wu, R.-F., De Vuyst, H., Plummer, M., Qiao, Y.-L. and Clifford, G. (2009) Different Cervical Cancer Screening Approaches in a Chinese Multicenter Study. British Journal of Cancer, 100, 532-537. https://doi.org/10.1038/sj.bjc.6604840

[14] Sauvaget, C., Fayette, J.M., Muwonge, R., Wesley, R. and Sankaranarayanan, R. (2011) Accuracy of Visual Inspection with Acetic Acid for Cervical Cancer Screening. International Journal of Gynecology \& Obstetrics, 113, 14-24. https://doi.org/10.1016/j.ijgo.2010.10.012

[15] Pretorius, R.G., et al. (2007) Inappropriate Gold Standard Bias in Cervical Cancer Screening Studies. International Journal of Cancer, 121, 2218-2224.

https://doi.org/10.1002/ijc.22991 
[16] The ASCUS-LSIL Trial Study (ALTS) Group (2003) A Randomized Trial on the Management of Low-Grade Squamous Intraepithelial Lesions Cytologic Interpretations. American Journal of Obstetrics \& Gynecology, 188, 1383-1392. https://doi.org/10.1067/mob.2003.462

[17] Gage, J.C., Hanson, V.W., Abbey, K., et al. (2006) Number of Cervical Biopsies and the Sensitivity of Colposcopy. Obstetrics \& Gynecology, 108, 264-272. https://doi.org/10.1097/01.AOG.0000220505.18525.85

[18] Schiffman, M. (2015) Issues in Optimising and Standardising the Accuracy and Utility of the Colposcopic Examination in the HPV Era. Ecancermedicalscience, 9, 530. https://doi.org/10.3332/ecancer.2015.530

[19] Guillaud, M., Benedet, J.L., Cantor, S.B., Staerkel, G., Follen, M. and MacAulay, C. (2006) DNA Ploidy Compared to Human Papilloma Virus Testing (Hybrid Capture II) and Conventional Cervical Cytology as a Primary Screening Test for Cervical High Grade Lesions and Cancer in 1555 Patients with Biopsy Confirmation. Cancer, 107, 309-318. https://doi.org/10.1002/cncr.21993

[20] Wilkinson, A. (2013) HPV Vaccine. Canadian Medical Association Journal, 2013, E527.

[21] Cuzick, J., Clavel, C., Petry, K.-U., Meijer, C.J.L.M., Hoyer, H., Ratnam, S., Szarewski, A., Birembaut, P., Kulasingam, S., Sasieni, P. and Iftner, T. (2006) Overview of the European and North American studies on HPV Testing in Primary Cervical Cancer Screening. International Journal of Cancer, 119, 1095-1101. https://doi.org/10.1002/ijc.21955

[22] Mandelblatt, J.S., Lawrence, W.F., Womack, S.M., Jacobson, D., Yi, B., Hwang, Y., Gold, K., Barter, J. and Shah, K. (2002) Benefits and Costs of Using HPV Testing to Screen for Cervical Cancer. JAMA, 287, 2372-2381. https://doi.org/10.1001/jama.287.18.2372

[23] Zeng, H. (2014) Diagnostic Endoscopy. Chapter 8. CRC Press, Boca Raton.

[24] Richards-Kortum, R., Mitchell, M.F., Ramanujam, N., Mahadevan, A. and Thomsen, S. (1994) In Vivo Fluorescence Spectroscopy: Potential for Non-Invasive, Automated Diagnosis of Cervical Intraepithelial Neoplasia and Use as a Surrogate Endpoint Biomarker. Journal of Cellular Biochemistry, 19, 111-119.

[25] Sokolov, K., Follen, M. and Richards-Kortum, R. (2002) Optical Spectroscopy for Detection of Neoplasia. Current Opinion in Chemical Biology, 6, 651-658. https://doi.org/10.1016/S1367-5931(02)00381-2

[26] Drezek, R., Richards-Kortum, R., Brewer, M., Feld, M., Pitris, C., Ferenczy, A., Faupel, M. and Follen, M. (2003) Optical Imaging of the Cervix. Cancer, 98, 2015-2027. https://doi.org/10.1002/cncr.11678

[27] Thekkek, N. and Richards-Kortum, R. (2008) Optical Imaging for Cervical Cancer Detection: Solutions for a Continuing Global Problem. Nature Reviews Cancer, 8 , 725. https://doi.org/10.1038/nrc2462

[28] Cardenas-Turanzas, M., Pikkula, B.M., MacAulay, C., Richards-Kortum, R., Follen, M. and Cantor, S.B. (2007) The Clinical Effectiveness of Optical Spectroscopy for the In Vivo Diagnosis of Cervical Intraepithelial Neoplasia. Gynecologic Oncology, 107, S138-S146. https://doi.org/10.1016/j.ygyno.2007.08.082

[29] Freeberg, J.A., Benedet, J.L., West, L.A., Atkinson, E.N., MacAulay, C. and Follen, M. (2007) The Clinical Effectiveness of Fluorescence and Reflectance Spectroscopy for the In Vivo Diagnosis of Cervical Neoplasia: An Analysis by Phase of Trial Design. Gynecologic Oncology, 107, S270-S280.

https://doi.org/10.1016/j.ygyno.2007.07.009 
[30] Freeberg, J.A., Benedet, J.L., MacAulay, C., West, L.A. and Follen, M. (2007) The Performance of Fluorescence and Reflectance Spectroscopy for the In Vivo Diagnosis of Cervical Neoplasia: Point Probe versus Multispectral Approaches. Gynecologic Oncology, 1, S248-S255. https://doi.org/10.1016/j.ygyno.2007.07.008

[31] Bazant-Hegemark, F., Edey, F., Swingler, G.R., Read, M.K. and Stone, N. (2008) Review: Optical Micrometer Resolution Scanning for Non-Invasive Grading of Precancer in the Human Uterine Cervix. Technology in Cancer Research, 7, 483-496. http://journals.sagepub.com/doi/abs/10.1177/153303460800700610 https://doi.org/10.1177/153303460800700610

[32] Bedard, N., Pierce, M., El-Naggar, A., Anandasabapathy, S., Gillenwater, A. and Richards-Kortum, R. (2010) Emerging Roles for Multimodal Optical Imaging in Early Cancer Detection: A Global Challenge. Technology in Cancer Research \& Treatment, 9, 211-217. https://doi.org/10.1177/153303461000900210

[33] Orfanoudaki, I.M., Kappou, D. and Sifakis, S. (2011) Recent Advances in Optical Imaging for Cervical Detection. Archives of Gynecology and Obstetrics, 284, 1197-1208. https://doi.org/10.1007/s00404-011-2009-4

[34] Liu, Q. (2011) Role of Optical Spectroscopy Using Endogenous Contrasts in Clinical Cancer Diagnosis. World Journal of Clinical Oncology, 10, 50-63.

https://doi.org/10.5306/wjco.v2.i1.50

[35] Boppart, S.A. and Richards-Kortum, R. (2014) Point-of-Care and Point-of-Procedure Optical Imaging Technologies for Primary Care and Global Health. Science Translational Medicine, 6, 253rv2. https://doi.org/10.1126/scitranslmed.3009725

[36] Lu, G. and Fei, B. (2014) Medical Hyperspectral Imaging: A Review. Journal of Biomedical Optics, 19, Article ID: 010901. https://doi.org/10.1117/1.JBO.19.1.010901

[37] Wang, S.M. and Qiao, Y.L. (2015) Implementation of Cervical Cancer Screening and Prevention in China-Challenges and Reality. Japanese Journal of Clinical Oncology, 45, 7-11. https://doi.org/10.1093/jjco/hyu188

[38] Jusman, Y., Ng, S.C. and Abu Osman, N.A. (2014) Intelligent Screening Systems for Cervical Cancer. The Scientific World Journal, 2014, Article ID 810368. https://doi.org/10.1155/2014/810368

[39] Yu, B., Ferris, D.G., Liu, Y. and Nagarajan, V.K. (2014) Emerging Optical Techniques for Detection of Oral, Cervical, and Anal Cancer in Low-Resource Settings. Austin Journal of Biomechanical Engineering, 1, 1007.

[40] Wang, C., Zheng, W., Bu, Y., Chang, S., Tong, Q., Zhang, S. and Xu, R.X. (2014) In Vivo and In Vitro Hyperspectral Imaging for Cervical Neoplasia. Proceedings of the SPIE, 8951, Article ID: 89510M.

[41] Novikova, T. (2017) Optical Techniques for Cervical Neoplasia Detection. Beilstein Journal of Nanotechnology, 8, 1844-1862. https://doi.org/10.3762/bjnano.8.186

[42] Mahadevan, A., Mitchell, M.F., Silva, E., Thomsen, S. and Richards-Kortum, R.R. (1993) Study of the Fluorescence Properties of Normal and Neoplastic Human Cervical Tissue. Lasers in Surgery and Medicine, 13, 647-655.

https://doi.org/10.1002/lsm.1900130609

[43] Mahadevan-Jansen, A., Mitchell, M.F., Ramanujam, N., Utzinger, U. and Richards-Kortum, R. (1998) Development of a Fiber Optic Probe to Measure NIR Raman Spectra of Cervical Tissue in Vivo. Photochemistry and Photobiology, 68, 427-431. https://doi.org/10.1111/j.1751-1097.1998.tb09703.x

[44] Brookner, C.K., Utzinger, U., Staerkel, G., Richards-Kortum, R. and Mitchell, M.F. (1999) Cervical Fluorescence of Normal Women. Lasers in Surgery and Medicine, 24, 29-37. https://doi.org/10.1002/(SICI)1096-9101(1999)24:1<29::AID-LSM6>3.0.CO;2-H 
[45] Utzinger, U., Trujillo, E.V., Atkinson, E.N., Mitchell, M.F., Cantor, S.B. and Richards-Kortum, R. (1999) Performance Estimation of Diagnostic Tests for Cervical Precancer Based on Fluorescence Spectroscopy: Effects of Tissue Type, Sample Size, Population and Signal-to-Noise Ratio. IEEE Transactions on Bio-Medical Engineering, 46, 1293-1303. https://doi.org/10.1109/10.797989

[46] Agrawal, A., Utzinger, U., Brookner, C., Pitris, C., Mitchell, M.F. and Richards-Kortum, R. (1999) Fluorescence Spectroscopy of the Cervix: Influence of Acetic Acid, Cervical Mucus, and Vaginal Medications. Lasers in Surgery and Medicine, 25, 237-249. https://doi.org/10.1002/(SICI)1096-9101(1999)25:3<237::AID-LSM8>3.0.CO;2-F

[47] Brookner, C.K., Follen, M., Boiko, I., Galvan, J., Thomsen, S., Malpica, A., Suzuki, S., Lotan, R. and Richards-Kortum, R. (2000) Autofluorescence Patterns in Short-Term Cultures of Normal Cervical Tissue. Photochemistry and Photobiology, 71, 730-736. https://doi.org/10.1562/0031-8655(2000)071<0730:APISTC >2.0.CO;2

[48] Coghlan, L., Utzinger, U., Drezek, R., Heintzelman, D., Zuluaga, A., Brookner, C., Richards-Kortum, R., Gimeniz-Conti, I. and Follen, M. (2000) Optimal Fluorescence Excitation Wavelengths for Detection of Squamous Intra-Epithelial Neoplasia: Results from an Animal Model. Optics Express, 7, 436-446.

https://doi.org/10.1364/OE.7.000436

[49] Ramanujam, N., Richards-Kortum, R., Thomsen, S., Mahadevan-Jansen, A., Follen, M. and Chance, B. (2001) Low Temperature Fluorescence Imaging of Freeze Trapped Human Cervical Tissues. Optics Express, 8, 335-343. https://doi.org/10.1364/OE.8.000335

[50] Coghlan, L., Utzinger, U., Richards-Kortum, R., Brookner, C., Zuluaga, A., Gimeniz-Conti, I. and Follen, M. (2001) Fluorescence Spectroscopy of Epithelial Tissue throughout the Dysplasia-Carcinoma Sequence in an Animal Model: Spectroscopic Changes Precede Morphologic Changes. Lasers in Surgery and Medicine, 29, 1-10. https://doi.org/10.1002/lsm.1078

[51] Drezek, R., Brookner, C., Pavlova, I., Boiko, I., Malpica, A., Lotan, R., Follen, M. and Richards-Kortum, R. (2001) Autofluorescence Microscopy of Fresh Cervical-Tissue Sections Reveals Alterations in Tissue Biochemistry with Dysplasia. Photochemistry and Photobiology, 73, 636-641. https://doi.org/10.1562/0031-8655(2001)0730636AMOFCT2.0.CO2

[52] Utzinger, U., Hentzelman, D.L., Mahadevan-Jansen, A., Malpica, A., Follen, M. and Richards-Kortum, R. (2001) Near-Infrared Raman Spectroscopy for In Vivo Detection of Cervical Precancers. Applied Spectroscopy, 55, 955-959. https://doi.org/10.1366/0003702011953018

[53] Drezek, R., Sokolov, K., Utzinger, U., Boiko, I., Malpica, A., Follen, M. and Richards-Kortum, R. (2001) Understanding the Contributions of NADH and Collagen to Cervical Tissue Fluorescence Spectra: Modeling, Measurements, and Implications. Journal of Biomedical Optics, 6, 385-396. https://doi.org/10.1117/1.1413209

[54] MacAulay, C., Richards-Kortum, R., Utzinger, U., Fedyk, A., Atkinson, E.N., Cox, D. and Follen, M. (2002) Variation of Fluorescence Spectroscopy during the Menstrual Cycle. Optics Express, 10, 493-504. https://doi.org/10.1364/OE.10.000493

[55] Trujillo, E.V., Sandison, D.R., Utzinger, U., Ramanujam, N., Mitchell, M.F. and Richards-Kortum, R. (1998) Method to Determine Tissue Fluorescence Efficiency in Vivo and Predict Signal to Noise Ratio for Spectrometers. Applied Spectroscopy, 52 , 943-951. https://doi.org/10.1366/0003702981944751

[56] Mahadevan-Jansen, A., Mitchell, M.F., Ramanujam, N., Malpica, A., Thomsen, S., Utzinger, U. and Richards-Kortum, R. (1998) Near-Infrared Raman Spectroscopy 
for In Vitro Detection of Cervical Precancers. Photochemistry and Photobiology, 68, 123-132. https://doi.org/10.1111/j.1751-1097.1998.tb03262.x

[57] Zuluaga, A.F., Drezek, R., Collier, T., Lotan, R., Follen, M. and Richards-Kortum, R. (2002) Contrast Agents for Confocal Microscopy: How Simple Chemicals Affect Confocal Images of Normal and Cancer Cells in Suspension. Journal of Biomedical Optics, 7, 398-403. https://doi.org/10.1117/1.1481047

[58] Chang, S.K., Dawood, M.Y., Staerkel, G., Utzinger, U., Atkinson, E.N., Richards-Kortum, R.R. and Follen, M. (2002) Fluorescence Spectroscopy for Cervical Precancer Detection: Is There Variance across the Menstrual Cycle? Journal of Biomedical Optics, 7 , 595-602. https://doi.org/10.1117/1.1509753

[59] Cox, D.D., Chang, S.K., Dawood, M.Y., Staerkel, G., Utzinger, U., Richards-Kortum, R.R. and Follen, M. (2003) Detecting the Signal from of Menstrual Cycle in Fluorescence Spectroscopy of the Cervix. Applied Spectroscopy, 57, 67-72. https://doi.org/10.1366/000370203321165223

[60] Drezek, R., Guillaud, M., Collier, T., Boiko, I., Malpica, A., MacAulay, C., Follen, M. and Richards-Kortum, R. (2003) Light Scattering from Cervical Cells throughout Neoplastic Progression: Influence of Nuclear Morphology, DNA Content, and Chromatin Texture. Journal of Biomedical Optics, 8, 7-16. https://doi.org/10.1117/1.1528950

[61] Brookner, C., Utzinger, U., Follen, M., Richards-Kortum, R., Cox, D. and Atkinson, E.N. (2003) Effects of Biographical Variables on Cervical Fluorescence Emission Spectra. Journal of Biomedical Optics, 8, 479-483. https://doi.org/10.1117/1.1578642

[62] Arifler, D., Guillaud, M., Malpica, A., Follen, M. and Richards-Kortum, R. (2003) Light Scattering from Normal and Dysplastic Cervical Cells at Different Epithelial Depths: Finite Difference Time Domain Modeling with a Perfectly Matched Layer Boundary Condition. Journal of Biomedical Optics, 8, 484-494. https://doi.org/10.1117/1.1578640

[63] Sokolov, K., Follen, M., Aaron, J., Pavlova, I., Malpica, A., Lotan, R. and Richards-Kortum, R. (2003) Real-Time Vital Optical Imaging of Precancer Using Anti-Epidermal Growth Factor Receptor Antibodies Conjugated to Gold Nanoparticles. Cancer Research, 63, 1999-2004.

[64] Pavlova, I., Sokolov, K., Drezek, R., Malpica, A., Follen, M. and Richards-Kortum, R. (2003) Microanatomical and Biochemical Origins of Normal and Precancerous Cervical Autofluorecence Using Laser Scanning Fluorescence Confocal Microscopy. Photochemistry and Photobiology, 77, 550-555. https://doi.org/10.1562/0031-8655(2003)077<0550:MABOON>2.0.CO;2

[65] Gill, E.M., Malpica, A., Alford, R.E., Nath, A.R., Follen, M., Richards-Kortum, R.R. and Ramanujam, N. (2003) Relationship between Collagen Autofluorescence of the Human Cervix and Menopausal Status. Photochemistry and Photobiology, 77, 653-658. https://doi.org/10.1562/0031-8655(2003)077<0653:RBCAOT>2.0.CO;2

[66] Nath, A., Rivoire, K., Chang, S., Cox, D., Atkinson, E.N., Follen, M. and Richards-Kortum, R. (2004) Effect of Probe Pressure on Cervical Fluorescence Spectroscopy Measurements. Journal of Biomedical Optics, 9, 523-533. https://doi.org/10.1117/1.1695562

[67] Guillaud, M., Cox, D., Adler-Storthz, K., Malpica, A., Staerkel, G., Matisic, J., van Niekerk, D., Poulin, N., Follen, M. and MacAulay, C. (2004) Exploratory Analysis of Quantitative Histopathology of Cervical Intraepithelial Neoplasia: Objectivity, Reproducibility, Malignancy-Associated Changes, and Human Papillomavirus. Cytometry Part A, 60, 81-89. https://doi.org/10.1002/cyto.a.20034

[68] Guillaud, M., Cox, D., Malpica, A., Staerkel, G., Matisic, J., Van Niekerk, D., Ad- 
ler-Storthz, K., Poulin, N., Follen, M. and MacAulay, C. (2004) Quantitative Histopathological Analysis of Cervical Intra-Epithelial Neoplasia Sections: Methodological Issues. Cellular Oncology, 26, 31-43. http://dx.doi.org/10.1155/2004/238769

[69] Chang, S.K., Arifler, D., Drezek, R., Follen, M. and Richards-Kortum, R. (2004) Analytical Model to Describe Fluorescence Spectra of Normal and Preneoplastic Epithelial Tissue: Comparison with Monte Carlo Simulations and Clinical Measurements. Journal of Biomedical Optics, 9, 511-522. https://doi.org/10.1117/1.1695559

[70] Nath, A., Rivoire, K., Chang, S., West, L., Cantor, S.B., Basen-Engquist, K., Adler-Storthz, K., Cox, D., Atkinson, E.N., Staerkel, G., MacAulay, C., Richards-Kortum, R. and Follen, M. (2004) A Pilot Study for a Screening Trial of Cervical Fluorescence Spectroscopy. International Journal of Gynecological Cancer, 14, 1097-1107. https://doi.org/10.1111/j.1048-891X.2004.14607.x

[71] Rivoire, K., Nath, A., Cox, D., Atkinson, E.N., Richards-Kortum, R. and Follen, M. (2004) The Effects of Repeated Spectroscopic Pressure Measurements on Fluorescence Intensity in the Cervix. American Journal of Obstetrics \& Gynecology, 191, 1606-1617. https://doi.org/10.1016/j.ajog.2004.05.015

[72] Chang, S.K., Pavlova, I., Marin, N.M., Follen, M. and Richards-Kortum, R. (2005) Fluorescense Spectroscopy as a Diagnostic Tool for Detecting Cervical Pre-Cancer. Gynecologic Oncology, 99, S61-S63. https://doi.org/10.1016/j.ygyno.2005.07.045

[73] Guillaud, M., Adler-Storthz, K., Malpica, A., Staerkel, G., Matisic, J., van Niekerk, D., Cox, D., Poulin, N., Follen, M. and MacAulay, C. (2005) Subvisual Chromatin Changes in Cervical Epithelium Measured by Texture Image Analysis and Correlated with HPV. Gynecologic Oncology, 99, S16-S23. https://doi.org/10.1016/j.ygyno.2005.07.037

[74] Atkinson, E.N. and Follen, M. (2005) Interactive Dynamic Graphical Techniques for the Exploration of Functional Data. Gynecologic Oncology, 99, S76-S83. https://doi.org/10.1016/j.ygyno.2005.07.048

[75] Lee, J.S., Shuhatovich, O., Price, R., Pikkula, B., Follen, M., MacKinnon, N., MacAulay, C., Knight, B., Richards-Kortum, R. and Cox, D. (2005) Design and Preliminary Analysis of a Study to Assess Intra-Device and Inter-Device Variability of Fluorescence Spectroscopy Instruments for Detecting Cervical Neoplasia. Gynecologic Oncology, 99, S98-S111. https://doi.org/10.1016/j.ygyno.2005.07.052

[76] Malpica, A., Matisic, J., van Niekerk, D., Crum, C.P., Staerkel, G., Yamal, J.M., Guillaud, M., Cox, D., Atkinson, E.N., Adler-Storthz, K., Poulin, N., MacAulay, C. and Follen, M. (2005) Kappa Statistics to Measure Interrater and Intrarater Agreement for 1790 Cervical Biopsy Specimens among Twelve Pathologists: Qualitative Histopathologic Analysis and Methodologic Issues. Gynecologic Oncology, 99, S38-S52. https://doi.org/10.1016/j.ygyno.2005.07.040

[77] Marin, N.M., Milbourne, A., Rhodes, H., Ehlen, T., Miller, D., Benedet, L., Richards-Kortum, R. and Follen, M. (2005) Diffuse Reflectance Patterns in Cervical Spectroscopy. Gynecologic Oncology, 99, S116-S120. https://doi.org/10.1016/j.ygyno.2005.07.054

[78] Chang, S.K., Marin, N., Follen, M. and Richards-Kortum, R. (2006) Model-Based Analysis of Clinical Fluorescence Spectroscopy for In Vivo Detection of Intraepithelial Dysplasia. Journal of Biomedical Optics, 11, Article ID: 024008. https://doi.org/10.1117/1.2187979

[79] Marin, N., MacKinnon, N., MacAulay, C., Chang, S.K., Atkinson, E.N., Cox, D., Serachitopol, D., Pikkula, D., Follen, M. and Richards-Kortum, R. (2006) Calibration Standards for Multi-Center Clinical Trials of Fluorescence Spectroscopy for In Vivo 
Diagnosis. Journal of Biomedical Optics, 11, Article ID: 014010. https://doi.org/10.1117/1.2166389

[80] Guillaud, M., Follen, M. and MacAulay, C. (2006) Quantitative Histopathological Analysis of CIN Sections. Cellular Oncology, 28, 61-62.

[81] Arifler, D., MacAulay, C., Follen, M. and Richards-Kortum, R. (2006) Spatially Resolved Reflectance Spectroscopy for Diagnosis of Cervical Pre-Cancer: Monte Carlo Modeling and Comparison to Clinical Measurements. Journal of Biomedical Optics, 11, Article ID: 064027. https://doi.org/10.1117/1.2398932

[82] van Niekerk, D., Guillaud, M., Matisic, J., Benedet, J.L., Follen, M. and MacAulay, C. (2007) Improving the Diagnosis of HG and LG SIL Using p16 and MIB1 Immuno-Staining: A Report of 447 Biopsies with Consensus Diagnosis and HPV HCII Testing. Gynecologic Oncology, 107, S233-S240. https://doi.org/10.1016/j.ygyno.2007.07.064

[83] Scheurer, M.E., Dillon, L.M., Chen, Z., Follen, M. and Adler-Storthz, K. (2007) Absolute Quantitative Real-Time Polymerase Chain Reaction for the Measurement of Human Papillomavirus E7 mRNA in Cervical Cytobrush Specimens. Infectious Agents and Cancer, 2, 8. https://doi.org/10.1186/1750-9378-2-8

[84] Scheurer, M.D., Guillaud, M., Tortolero-Luna, G., MacAulay, C., Follen, M. and Adler-Storthz, K. (2007) Human Papillomavirus-Related Cedllular Changes Measured by Cytometric Analysis of DNA Ploidy and Chromatin Texture. Cytometry Part B: Clinical Cytometry, 72, 324-331. https://doi.org/10.1002/cyto.b.20173

[85] Freeberg, J.A., Serachitopol, D.M., MacKinnon, N., Price, R., Atkinson, E.N., Cox, D.D., MacAulay, C., Richards-Kortum, R., Follen, M. and Pikkula, B. (2007) Fluorescence and Reflectance Device Variability throughout the Progression of a Phase II Clinical Trial to Detect and Screen for Cervical Neoplasia Using a Fiber Optic Probe. Journal of Biomedical Optics, 12, Article ID: 034015. https://doi.org/10.1117/1.2750332

[86] Pikkula, B.M., Shuhatovich, O., Price, R.L., Serachitopol, D.M., Follen, M., MacKinnon, N., MacAulay, C., Richards-Kortum, R., Lee, J.S., Atkinson, E.N. and Cox, D.D. (2007) Instrumentation as a Source of Variability in the Application of Fluorescence Spectroscopic Devices for Detecting Cervical Neoplasia. Journal of Biomedical Optics, 12, Article ID: 034015. https://doi.org/10.1117/1.2745285

[87] Pham, B., Earle, N., Rabel, K., Follen, M. and Scheurer, M.E. (2007) Maximizing the Diversity of Participants in Phase II Trial Clinical Trials of Optical Technologies to Detect Cervical Neoplasia. Gynecologic Oncology, 107, S208-214. https://doi.org/10.1016/j.ygyno.2007.07.063

[88] Scheurer, M.D., Guillaud, M., Tortolero-Luma, G., Follen, M. and Adler-Storthz, K. (2007) Epidemiologic Modeling of Cervical Dysplasia with Molecular and Cytopathological Markers. Gynecologic Oncology, 107, S163-S169.

https://doi.org/10.1016/j.ygyno.2007.07.050

[89] Lee, J.S., Follen, M., MacAulay, C., Pikkula, B., Serachitopol, D.M., Price, R. and Cox, D. (2007) Sources of Variability in Fluorescence Spectroscopic Measurements in a Phase II Clinical Trial of 850 Patients. Gynecologic Oncology, 107, S260-S269. https://doi.org/10.1016/j.ygyno.2007.07.012

[90] Brookner, C.K., Agrawal, A., Trujillo, E.V., Mitchell, M.F. and Richards-Kortum, R.R. (1997) Safety Analysis: Relative Risks of Ultraviolet Exposure from Fluorescence Spectroscopy and Colposcopy Are Comparable. Photochemistry and Photobiology, 65, 1020-1025. https://doi.org/10.1111/j.1751-1097.1997.tb07963.x

[91] Yu, C.C., Lau, C., O’Donoghue, G., Mirkovic, J., McGee, S., Galindo, L., Elackattu, 
A., Stier, E., Grillone, G., Badizadegan, K., Dasari, R.R. and Feld, M.S. (2008) Quantitative Spectroscopic Imaging for Non-Invasive Early Cancer Detection. Optics EXpress, 16, Article ID: 16227. https://doi.org/10.1364/OE.16.016227

[92] Shadeo, A., Chari, R., Lonergan, K.M., Pusic, A., Miller, D., Ehlen, T., van Niekerk, D., Matisic, J., Richards-Kortum, R., Follen, M., Guillaud, M., Lam, W.L. and MacAulay, C. (2008) Up Regulation in Gene Expression of Chromatin Remodeling Factors in Cervical Intraepithelial Neoplasia. BMC Genomics, 9, 64.

https://doi.org/10.1186/1471-2164-9-64

[93] Brown, J.Q., Vishwanath, K., Palmer, G.M. and Ramanujam, N. (2009) Advances in Quantitative UV-Visible Spectroscopy for Clinical and Pre-Clinical Application in Cancer. Current Opinion in Biotechnology, 20, 119-131. https://doi.org/10.1016/j.copbio.2009.02.004

[94] Chang, V.T.-C., Cartwright, P., Bean, S.M., Palmer, G.M., Bentley, R.C. and Ramanujam, N. (2009) Quantitative Physiology of the Precancerous Cervix in Vivo through Optical Spectroscopy. Neoplasia, 11, 325-332. https://doi.org/10.1593/neo.81386

[95] Ebenezar, J., Aruna, P. and Ganesan, S. (2010) Synchronous Fluorescence Spectroscopy for the Detection and Characterization of Cervical Cancers in Vitro. Journal of Photochemistry and Photobiology, 86, 77-86. https://doi.org/10.1111/j.1751-1097.2009.00628.x

[96] Yamal, J.M., Cox, D.D., Atkinson, E.N., Macaulay, C., Price, R. and Follen, M. (2010) Repeatability of Tissue Fluorescence Measurements for the Detection of Cervical Intraepithelial Neoplasia. Biomedical Optics Express, 1, 641-657.

https://doi.org/10.1364/BOE.1.000641

[97] Yamal, J.M., Follen, M., Guillaud, M. and Cox, D.D. (2011) Classifying Tissue Samples from Measurements on Cells with Within-Class Tissue Sample Heterogeneity. Biostatistics, 12, 695-709. https://doi.org/10.1093/biostatistics/kxr010

[98] Buys, T.P., Cantor, S.B., Guillaud, M., Adler-Storthz, K., Cox, D.D., Okolo, C., Arulogon, O., Oladepo, O., Basen-Engquist, K., Shinn, E., Yamal, J.M., Beck, J.R., Scheurer, M.E., van Niekerk, D., Malpica, A., Matisic, J., Staerkel, G., Atkinson, E.N., Bidaut, L., Lane, P., Benedet, J.L., Miller, D., Ehlen, T., Price, R., Adelwole, I.F., Macaulay, C. and Follen, M. (2012) Optical Technologies and Molecular Imaging for Cervical Neoplasia: A Program Project Update. Gender Medicine, 9, S7-S24. https://doi.org/10.1016/j.genm.2011.08.002

[99] Lane, P., Au, S., Follen, M. and MacAulay, C. (2012) Oral Fluorescence Imaging Using $405 \mathrm{~nm}$ Excitation, Aiding the Discrimination of Cancers and Precancers by Identifying Changes in Collagen and Elastic Breakdown and Neovasularization in the Underlying Stroma. Gender Medicine, 9, S78-S82.

https://doi.org/10.1016/j.genm.2011.11.006

[100] Pham, B., Rhodes, H., Milbourne, A., Adler-Storthz, K., Follen, M. and Scheurer, M.E. (2012) Epidemiologic Differentiation of Diagnostic and Screening Populations for the Assessment of Cervical Dysplasia Using Optical Technologies. Gender Medicine, 9, S36-S47. https://doi.org/10.1016/j.genm.2011.10.006

[101] Li, G., Guillaud, M., Follen, M. and MacAulay, C. (2012) Double Staining Cytologic Samples with Quantitative Feulgen-Thionin and Anti-Ki-67 Immunocytochemistry as a Method of Distinguishing Cells with Abnormal DNA Content from Normal Cycling Cells. Analytical and Quantitative Cytology and Histology, 34, 273-284. PMCID: PMC3573880, NIHMSID: NIHMS433101.

[102] Luu, H.N., Adler-Storthz, K., Dillon, L.M., Follen, M. and Scheurer, M.E. (2013) Comparing the Performance of Hybrid Capture II and Polymerase Chain Reaction 
(PCR) for the Identification of Cervical Dysplasia in the Screening and Diagnostic Settings. Clinical Medicine Insights. Oncology, 7, 247-255. https://doi.org/10.4137/CMO.S12811

[103] Arifler, D., Macaulay, C., Follen, M. and Guillaud, M. (2014) Numerical Investigation of Two-Dimensional Light Scattering Patterns of Cervical Cell Nuclei to Map Dysplastic Changes at Different Epithelial Depths. Biomedical Optics Express, 5, 485-498. https://doi.org/10.1364/BOE.5.000485

[104] Wang, L., Lee, J.S., Lane, P., Atkinson, E.N., Zuluaga, A., Follen, M., MacAulay, C. and Cox, D.D. (2014) A Statistical Model for Removing Inter-Device Differences in Spectroscopy. Optics Express, 22, 7617-7624. https://doi.org/10.1364/OE.22.007617

[105] Tabrizi, S.H., et al. (2013) The Use of Optical Spectroscopy for In Vivo Detection of Cervical Pre-Cancer. Lasers in Medical Science, 29, 831-845.

https://doi.org/10.1007/s10103-013-1288-3

[106] MacAulay, C.E., Poh, C., Durham, S., Zhang, L.W., Rosin, M., Guillaud, M., McAlpine, J., Miller, D., Ehlen, T., Van Niekerk, D., Follen, M. and Lane, P.M. (2013) Fluorescence Visualization and Imaging: A Tool for Improving Patient Outcomes for Oral and (Hopefully) Other Cancers. OSA Technical Digest.

https://doi.org/10.1364/BODA.2013.JW4A.3

[107] Gajjar, K., et al. (2014) Histology Verification Demonstrates That Biospectroscopy Analysis of Cervical Cytology Identifies Underlying Disease More Accurately than Conventional Screening: Removing the Confounder of Discordance. PLoS ONE, 9, 0082416. https://doi.org/10.1371/journal.pone.0082416

[108] Guillaud, M., Buys, T.P.H., Carraro, A., Korbelik, J., Follen, M., Scheurer, M., Adler-Storthz, K., Van Niekerk, D. and MacAulay, C.E. (2014) Evaluation of HPV Infection and Smoking Status Impacts on Cell Proliferation in Epithelial Layers of Cervical Neoplasia. PLoS ONE, 9, 0107088.

https://doi.org/10.1371/journal.pone.0107088

[109] Mitchell, M.F., Schottenfeld, D., Tortolero-Luna, G., Cantor, S.B. and Richards-Kortum, R. (1998) Colposcopy for the Diagnosis of Squamous Intraepithelial Lesions: A Meta-Analysis. Obstetrics \& Gynecology, 91, 626-631. https://doi.org/10.1097/00006250-199804000-00029

[110] Cantor, S.B., Cardenas-Turanzas, M., Cox, D.D., Atkinson, E.N., Nogueras-Gonzalez, G.M., Beck, J.R., Follen, M. and Benedet, J.L. (2008) Accuracy of Colposcopy in the Diagnostic Compared with the Screening Setting. Obstetrics \& Gynecology, 111, 7-14. https://doi.org/10.1097/01.AOG.0000295870.67752.b4

[111] Ramanujam, N., Mitchell, M.F., Mahadevan, A., Thomsen, S., Silva, E. and Richards-Kortum, R. (1994) Fluorescence Spectroscopy: A Diagnostic Tool for Cervical Intraepithelial Neoplasia (CIN). Gynecologic Oncology, 52, 31-38. https://doi.org/10.1006/gyno.1994.1007

[112] Ramanujam, N., Mitchell, M.F., Mahadevan, A., Warren, S., Thomsen, S., Silva, E. and Richards-Kortum, R. (1994) In Vivo Diagnosis of Cervical Intraepithelial Neoplasia Using 337-nm-Excited Laser Induced Fluorescence. Proceedings of the National Academy of Sciences of the United States of America, 91, 10193-10197. https://doi.org/10.1073/pnas.91.21.10193

[113] Atkinson, E.N., Mitchell, M.F., Ramanujam, N. and Richards-Kortum, R. (1995) Statistical Techniques for Diagnosing CIN Using Fluorescence Spectroscopy: SVD and CART. Journal of Cellular Biochemistry, 23, 125-130. https://doi.org/10.1002/jcb.240590916

[114] Ramanujam, N., Mitchell, M.F., Mahadevan, A., Thomsen, S., Malpica, A., Wright, T., 
Atkinson, N. and Richards-Kortum, R. (1996)Development of a Multivariate Statistical Algorithm to Analyze Human Cervical Tissue Fluorescence Spectra Acquired In Vivo. Lasers in Surgery and Medicine, 19, 46-62. https://doi.org/10.1002/(SICI)1096-9101(1996)19:1<46::AID-LSM7>3.0.CO;2-Q

[115] Ramanujam, N., Mitchell, M.F., Mahadevan, A., Thomsen, S., Malpica, A., Wright, T., Atkinson, N. and Richards-Kortum, R. (1996)Spectroscopic Diagnosis of Cervical Intraepithelial Neoplasia (CIN) In Vivo Using Laser-Induced Fluorescence Spectra at Multiple Excitation Wavelengths. Lasers in Surgery and Medicine, 19, 63-74. https://doi.org/10.1002/(SICI)1096-9101(1996)19:1<63::AID-LSM8>3.0.CO;2-O

[116] Ramanujam, N., Mitchell, M.F., Mahadevan-Jansen, A., Thomsen, S.L., Staerkel, G., Malpica, A., Wright, T., Atkinson, N. and Richards-Kortum, R. (1996) Cervical Precancer Detection Using a Multivariate Statistical Algorithm Based on Laser Induced Fluorescence Spectra at Multiple Excitation Wavelengths. Photochemistry and Photobiology, 64, 720-735. https://doi.org/10.1111/j.1751-1097.1996.tb03130.x

[117] Ramanujam, N., Mitchell, M.F., Mahadevan-Jansen, A., Thomson, S.L., Staerkel, G. and Malpica, A. (1996) Cervical Precancer Detection Using a Multivariate Statistical Algorithm Based on Laser-Induced Fluorescence Spectra at Multiple Excitation Wavelengths. Photochemistry and Photobiology, 64, 720-735. https://doi.org/10.1111/j.1751-1097.1996.tb03130.x

[118] Mitchell, M.F., Cantor, S.B., Ramanujam, N., Tortolero-Luna, G. and Richards-Kortum, R. (1999) Fluorescence Spectroscopy for Diagnosis of Squamous Intraepithelial Lesions of the Cervix. Obstetrics \& Gynecology, 93, 462-470. https://doi.org/10.1016/S0029-7844(98)00385-8

[119] Mitchell, M.F., Cantor, S.B., Brookner, C., Utzinger, U., Schottenfeld, D. and Richards-Kortum, R. (1999) Screening for Squamous Intraepithelial Lesions with Fluorescence Spectroscopy. Obstetrics \& Gynecology, 94, 889-896. https://doi.org/10.1016/S0029-7844(99)00408-1

[120] Weingandt, H., Stepp, H., Baumgartner, R., Diebold, J., Xiang, W. and Hillemans, P. (2002) Autofluorescence Spectroscopy for the Diagnosis of Cervical Intraepithelial Neoplasia. An International Journal of Obstetrics \& Gynaecology, 109, 947-951. https://doi.org/10.1111/j.1471-0528.2002.01311.x

[121] Belinson, J., Qiao, Y.L., Pretorius, R., Zhang, W.H., Elson, P., Li, L., et al. (2001) Shanxi Province Cervical Cancer Screening Study: A Cross-Sectional Comparative Study of Multiple Techniques to Detect Cervical Neoplasia. Gynecologic Oncology, 83, 439-444. https://doi.org/10.1006/gyno.2001.6370

[122] Chang, S.K., Follen, M., Malpica, A., Utzinger, U., Staerkel, G., Cox, D., Atkinson, E.N., MacAulay, C. and Richards-Kortum, R. (2002) Optimal Excitation Wavelengths for Discrimination of Cervical Neoplasia. IEEE Transactions on Biomedical Engineering, 49, 1102-1111. https://doi.org/10.1109/TBME.2002.803597

[123] Parker, M.F., Mooradian, G.C., Karins, J.P., O’Connor, D.M., Speer, B.A., Owensby, P.D., et al. (2000) Multispectral Diagnostic Imaging of the Cervix: Report on a New Investigational Device. Journal of Lower Genital Tract Disease, 4, 119-124. https://doi.org/10.1097/00128360-200004030-00001

[124] Parker, M.F., Mooradian, G.C., Okimoto, G.S., O’Conner, D.M., Miyazawa, K. and Saggese, S.J. (2002) Initial Neural Net Construction for the Detection of Cervical Intraepithelial Neoplasia by Fluorescence Imaging. American Journal of Obstetrics \& Gynecology, 187, 398-402. https://doi.org/10.1067/mob.2002.123940

[125] Wright, T., Ferenczy, A., Wray, S., Christinson, R. and Ganguly, D. (1999) Detection of Cervical Squamous Intraepithelial Lesion Using Evoked Tissue Fluorescence. 
Abstracts for 30th Annual Meeting of the Society of Gynecologic Oncologists. Gynecologic Oncology, 72, 45.

[126] Dattamajundar, A.K., Wells, D., Parnell, J., Lewis, J.T., Ganguly, D. and Wright, T.C. (2001) Preliminary Experimental Results from Multi-Center Clinical Trials for Detection of Cervical Precancerous Lesions Using the Cervical Scan System: A Novel Full Field Evoked Tissue Fluorescence Based Imaging Instrument. Annual Reports of the Research Reactor Institute. Kyoto University, 3150-3152.

[127] Coppleson, M., Reid, B.L., Skladnex, V.N. and Dalrymple, J.C. (1994) An Electronic Approach to the Detection of Precancer and Cancer of the Uterine Cervix-A Preliminary Evaluation of the Polar Probe. International Journal of Gynecological Cancer, 4, 79-83. https://doi.org/10.1046/j.1525-1438.1994.04020079.x

[128] Singer, A., Coppleson, M., Canfell, K., Skladnev, V., Mackellar, G., Pisal, N., et al. (2003) A Real Time Optoelectronic Device as an Adjunct to the Pap Smear for Cervical Screening, a Multicenter Evaluation. International Journal of Gynecological Cancer, 13, 804-811. https://doi.org/10.1111/j.1525-1438.2003.13393.x

[129] Mirabal, Y.N., Chang, S.K., Atkinson, E.N., Malpica, A., Follen, M. and Richards-Kortum, R. (2002) Reflectance Spectroscopy for In Vivo Detection of Cervical Precancer. Journal of Biomedical Optics, 7, 587-594. https://doi.org/10.1117/1.1502675

[130] Mourant, J.R., Bocklage, J.T., Powers, T.M., Greene, H.M., Bullock, K.J., Marr-Lyon, L.R., et al. (2007) In Vivo Light Scattering Measurements for Detection of Precancerous Conditions of the Cervix. Gynecologic Oncology, 105, 439-445. https://doi.org/10.1016/j.ygyno.2007.01.001

[131] Chidananda, S.M., Satyamoorthy, K., Rai, L., Manjunath, A.P. and Kartha, V.B. (2006) Optical Diagnosis of Cervical Cancer by Fluorescence Spectroscopy Technique. International Journal of Cancer, 119, 139-145. https://doi.org/10.1002/ijc.21825

[132] Chilakapati, M., et al. (2008) An Overview on Applications of Optical Spectroscopy in Cervical Cancers. Journal of Cancer Research and Therapeutics, 4, 26. https://doi.org/10.4103/0973-1482.39602

[133] Orfanoudaki, I.M., Themelis, G.C., Sifakis, S.K., Fragouli, D.H., Panayiotidis, J.G., Vazgiouraki, E.M., et al. (2005) A Clinical Study of Optical Biopsy of the Cervix Using a Multispectral Imaging System. Gynecologic Oncology, 96, 119-131. https://doi.org/10.1016/j.ygyno.2004.09.013

[134] Georgakoudi, I., Sheets, E.E., Muller, M.G., Backman, V., Crum, C.P., Badizadegan, K., et al. (2002) Trimodal Spectroscopy for the Detection and Characterization of Cervical Precancers in Vivo. American Journal of Obstetrics \& Gynecology, 186, 374-382. https://doi.org/10.1067/mob.2002.121075

[135] Chang, S.K., Mirabal, Y., Atkinson, E.N., Cox, D., Malpica, A., Follen, M. and Richards-Kortum, R. (2005) Combined Reflectance and Fluorescence Spectroscopy for In Vivo Detection of Cervical Pre-Cancer. Journal of Biomedical Optics, 10, 2-31. https://doi.org/10.1117/1.1899686

[136] Cantor, S.B., Yamal, J.M., Guillaud, M., Cox, D.D., Atkinson, E.N., Benedet, J.L., Miller, D., Ehlen, T., Matisic, J., van Niekerk, D., Bertrand, M., Milbourne, A., Rhodes, H., Malpica, A., Staerkel, G., Nader-Eftekhari, S., Adler-Storthz, K., Scheurer, M.E., Basen-Engquist, K., Shinn, E., West, L.A., Vlastos, A.T., Tao, X., Beck, J.R., Macaulay, C. and Follen, M. (2011) Accuracy of Optical Spectroscopy for the Detection of Cervical Intraepithelial Neoplasia: Testing a Device as an Adjunct to Colposcopy. International Journal of Cancer, 128, 1151-1168. https://doi.org/10.1117/1.1899686

[137] Yamal, J.M., Zewdie, G.A., Cox, D.D., Atkinson, E.N., Cantor, S.B., MacAulay, C., Davies, K., Adeowole, I., Buys, T.P. and Follen, M. (2012) Accuracy of Optical Spec- 
troscopy for the Detection of Cervical Intraepithelial Neoplasia without Colposcopic Tissue Information; A Step toward Automation for Low Resource Settings. Journal of Biomedical Optics, 17, Article ID: 047002. https://doi.org/10.1117/1.JBO.17.4.047002

[138] Ferris, D.G., Lawhead, R.A., Dickman, E.D., Holtzapple, N., Miller, J.A., Grogan, S., et al. (2001) Multimodal Multi-Spectral Imaging for the Noninvasive Diagnosis of Cervical Neoplasia. Journal of Lower Genital Tract Disease, 5, 65-72.

[139] De Santis, T., Chakjtoura, N., Twiggs, L., Ferris, D., Lashgari, M., Flowers, L., et al. (2007) Spectroscopic Imaging as a Triage Test for Cervical Disease: A Prospective Multicenter Clinical Trial. Journal of Lower Genital Tract Disease, 11, 18-24. https://doi.org/10.1097/01.lgt.0000230207.50495.05

[140] Benevides, J.M., Chang, S., Park, S.Y., Richards-Kortum, R., Mackinnon, N., MacAulay, C., Milbourne, A., Malpica, A. and Follen, M. (2003) Multispectral Digitial Colposcopy for In Vivo Detection of Cervical Cancer. Optics Express, 11, 1223-1236. https://doi.org/10.1364/OE.11.001223

[141] Milbourne, A., Park, S.Y., Benedet, J.L., Miller, D., Ehlen, T., Rhodes, H., Malpica, A., Matisic, J., van Niekerk, D., Atkinson, E.N., Hadad, N., MacKinnon, N., MacAulay, C., Richards-Kortum, R. and Follen, M. (2005) Results of a Pilot Study of Multispectral Digital Colposcopy for the In Vivo Detection of Cervical Intraepithelial Neoplasia. Gynecologic Oncology, 99, S67-S75.

https://doi.org/10.1016/j.ygyno.2005.07.047

[142] Werner, C.L., et al. (2007) Comparison of Human Papilloma Virus Testing and Spectroscopy Combined with Cervical Cytology for the Detection of High-Grade Cervical Neoplasia. Journal of Lower Genital Tract Disease, 11, 73-79. https://doi.org/10.1097/01.lgt.0000230208.58118.58

[143] Twiggs, L.B., et al. (2013) Multimodal Hyperspectroscopy as a Triage Test for Cervical Neoplasia: Pivotal Clinical Trial Results. Gynecologic Oncology, 130, 147-151. https://doi.org/10.1016/j.ygyno.2013.04.012

[144] Burke, L., Niloff, J., Kobelin, M., Abu-Jawdeh, G., Zelenchuk, A. and Modell, M. (1996) Use of Autofluorescence of Cells to Evaluate Cervical Neoplasia. Journal of Lower Genital Tract Disease, 1, 25. https://doi.org/10.1097/00128360-199701000-00021

[145] Burke, L., Modell, M., Niloff, J., Kobelin, M., Abu-Jawdeh, G. and Zelenchuk, A. (1999) Identification of Squaous Intraepithelial Lesions: Fluorescence of Cervical Tissue during Colposcopy. Journal of Lower Genital Tract Disease, 3, 159-160. https://doi.org/10.1046/j.1526-0976.1999.08109.x

[146] Nordstrom, R.J., Burke, L., Niloff, J.M. and Myrtle, J.F. (2001) Identification of Cervical Intraepithelial Neoplasia (CIN) Using UV-Excited Fluorescence and Diffuse Reflectance Tissue Spectroscopy. Lasers in Surgery and Medicine, 2, 118-127. https://doi.org/10.1002/lsm.1097

[147] Huh, W.K., Cestero, R.M., Garcia, F.A., Gold, M.A., Guido, R.S., McIntyre-Seltman, K., et al. (2004) Optical Detection of High-Grade Cervical Intraepithelial Neoplasia in Vivo: Results of a 604-Patient Study. American Journal of Obstetrics \& Gynecology, 190, 1249-1257. https://doi.org/10.1016/j.ajog.2003.12.006

[148] Alvarez, R.D. and Wright, T.C. (2007) Optical Detection Group. Effective Cervical Neoplasia Detection with a Novel Optical Detection System: A Randomized Trial. Gynecologic Oncology, 104, 281-289. https://doi.org/10.1016/j.ygyno.2006.08.056

[149] Park, S.Y., Follen, M., Milbourne, A., Rhodes, H., Malpica, A., MacKinnon, N., MacAulay, C., Markey, M.K. and Richards-Kortum, R. (2008) Automated Image Analysis of Digital Colposcopy for the Detection of Cervical Neoplasia. Journal of Bio- 
medical Optics, 13, Article ID: 014029. https://doi.org/10.1117/1.2830654

[150] Tan, J., et al. (2009) Detection of Cervical Intraepithelial Neoplasia in Vivo Using Confocal Endomicroscopy. BJOG: An International Journal of Obstetrics \& Gynaecology, 116, 1663-1670. https://doi.org/10.1111/j.1471-0528.2009.02261.x

[151] Quinn, M.K., et al. (2012) High-Resolution Microendoscopy for the Detection of Cervical Neoplasia in Low-Resource Settings. PLoS ONE, 7, e44924. https://doi.org/10.1371/journal.pone.0044924

[152] Pierce, M.C., et al. (2012) A Pilot Study of Low-Cost, High-Resolution Microendoscopy as a Tool for Identifying Women with Cervical Precancer. Cancer Prevention Research, 5, 1273-1279. https://doi.org/10.1158/1940-6207.CAPR-12-0221

[153] Hong, X., et al. (2016)Smartphone Microendoscopy for High Resolution Fluorescence Imaging. Journal of Innovative Optical Health Sciences, 9, Article ID: 1650046. https://doi.org/10.1142/S1793545816500462

[154] Nakappan, S., Park, S.Y., Serachitopol, D., Price, R., Cardeno, M., Au, S., MacKinnon, N., MacAulay, C., Follen, M. and Pikkula, B.M. (2007) Methodology of a Real-Time Quality Control for the Multispectral Digital Colposcope (MDC).Gynecologic Oncology, 107, S215-S222. https://doi.org/10.1016/j.ygyno.2007.07.016

[155] Zarei, N., Cox, D.D., Lane, P., Cantor, S.B., Atkinson, E.N., Yamal, J.M. and Miller, D. (2017) Boosted Tree Classifier for In Vivo Identification of Early Cervical Cancer Using Multispectral Digital Colposcopy. Bioimaging, 2017, 85-91. https://doi.org/10.5220/0006148900850091

[156] Balas, D.J., Themelis, G.C., Prokopakis, I., Koumantakis, E. and Helidonis, E.S. (1999) In Vivo Detection of Epithelial Dysplasias and Malignancies Based on the Quantitative Assessment of Acetic Acid-Tissue Interaction Kinetics. Journal of Photochemistry and Photobiology B, 53, 153-157. https://doi.org/10.1016/S1011-1344(99)00133-5

[157] Balas, C. (2001) A Novel Optical Imaging Method for the Early Detection, Quantitative Grading, and Mapping of Cancerous and Precancerous Lesions of Cervix. IEEE Transactions on Biomedical Engineering, 48, 96-104. https://doi.org/10.1109/10.900259

[158] Balas, C. (2009) Review of Biomedical Optical Imaging-A Powerful, Non-Invasive, Non-Ionizing Technology for Improving In Vivo Diagnosis. Measurement Science and Technology, 20, Article ID: 104020. https://doi.org/10.1088/0957-0233/20/10/104020

[159] Roensbo, M.T., et al. (2015) Can Dynamic Spectral Imaging System Colposcopy Replace Conventional Colposcopy in the Detection of High-Grade Cervical Lesions? Acta Obstetricia et Gynecologica Scandinavica, 94, 781-785. https://doi.org/10.1111/aogs.12646

[160] Livingston, J. and Papagiannakis, E. (2016) How Colposcopy Misses Invasive Cervical Cancer: A Case Report from the IMPROVE-COLPO Study. Case Reports in Obstetrics and Gynecology, 2016, 1-4. https://doi.org/10.1155/2016/5857370

[161] Orfankoudi, I., Themelis, G., Sifakis, S., et al. (2005) A Clinical Study of Optical Biopsy of the Uterine Cervix Using a Multipspectral Imaging System. Gynecologic Oncology, 96, 119-131. https://doi.org/10.1016/j.ygyno.2004.09.013

[162] Soutter, W.P., et al. (2009) Dynamic Spectral Imaging: Improving Colposcopy. Clinical Cancer Research, 15, 1814-1820. https://doi.org/10.1158/1078-0432.CCR-08-1636

[163] Louwers, J., et al. (2010) Dynamic Spectral Imaging Colposcopy: Higher Sensitivity 
for Detection of Premalignant Cervical Lesions. BJOG: An International Journal of Obstetrics \& Gynaecology, 118, 309-318.

https://doi.org/10.1111/j.1471-0528.2010.02806.x

[164] Zaal, A., et al. (2012) Agreement between Colposcopic Impression and Histological Diagnosis among Human Papillomavirus Type 16-Positive Women: A Clinical Trial Using Dynamic Spectral Imaging Colposcopy. BJOG: An International Journal of Obstetrics \& Gynaecology, 119, 537-544. https://doi.org/10.1111/j.1471-0528.2012.03280.x

[165] Prabitha, V.G., et al. (2014) Multi-Spectral Diffuse Reflectance Imaging for Detection of Cervical Lesions. International Journal of Engineering Science and Innovative Technology, 3, 169-177.

[166] Coronado, P.J. and Fasero, M. (2016) Colposcopy Combined with Dynamic Spectral Imaging. A Prospective Clinical Study. European Journal of Obstetrics \& Gynecology and Reproductive Biology, 196, 11-16. https://doi.org/10.1016/j.ejogrb.2015.09.007

[167] Coronado, P.J. and Fasero, M. (2014) Correlating the Accuracy of Colposcopy with Practitioner Experience When Diagnosing Cervical Pathology Using the Dynamic Spectral Imaging System. Gynecologic and Obstetric Investigation, 78, 224-229. https://doi.org/10.1159/000365087

[168] Denardis, S.A., et al. (2017) Increased Detection of Precancerous Cervical Lesions with Adjunctive Dynamic Spectral Imaging. International Journal of Women's Health, 9, 717-725. https://doi.org/10.2147/IJWH.S144577

[169] Cholkeri-Singh, A., et al. (2017) Digital Colposcopy with Dynamic Spectral Imaging for Detection of Cervical Intraepithelial Neoplasia 2 in Low-Grade Referrals. Journal of Lower Genital Tract Disease, 2017, 1. https://doi.org/10.1097/LGT.0000000000000353

[170] MacAulay, C.E., Poh, C., Rosin, M., Lam, S., Follen, M., Pahlevaninezhad, H. and Lane, P. (2015) Multiple Roles for Autofluorescence (AF) Visualization, Multispectral AF, and Reflectance Imaging and AF-OCT for Early Cancer Detection and Management. OSA Technical Digest. https://doi.org10.1364/BODA.2015.BT4A.1

[171] Kendrick, J.E., Huh, W.H. and Alvarez, R.D. (2007) LUMA Cervical Imaging System. https://www.future-drugs.com

[172] Twiggs, L. (2013) Is Colposcopy and/or Biopsy Always Necessary? LuViva Advanced Cervical Scan Is Designed as a New Non-Invasive Test that Has the potential to Significantly Improve the Early Detection of Cervical Precancers. 1-3. https://www.hospitalhealthcare.com/hhe

[173] Pitris, C., Goodman, A., Boppart, S.A., Libus, J.J., Fujimoto, J.G. and Brezinski, M.E. (1999) High Resolution Imaging of Gynecologic Neoplasms Using Optical Coherence Tomography. Obstetrics \& Gynecology, 93, 135-139. https://doi.org/10.1097/00006250-199901000-00027

[174] Fujimoto, J.G., Pitris, C., Boppart, S.A. and Brezinski, M.E. (2000) Optical Coherence Tomography: An Emerging Technology for Biomedical Imaging and Optical Biospy. Neoplasia, 2, 9-25. https://doi.org/10.1038/sj.neo.7900071

[175] Escobar, P.F., Belinson, J.L., White, A., Shakova, N.M., Feldchtein, F.I., Kareta, M.V. and Gladkova, D.(2004) Diagnsotic Efficacy of Optical Coherence Tomography in the Management of Preinvasive and Invasive Cancer of Uterine Cervix and Vulva. International Journal of Gynecological Cancer, 14, 470-474. https://doi.org/10.1111/j.1048-891x.2004.14307.x

[176] Zuluaga, A.F., Follen, M., Boiko, I., Malpica, A. and Richards-Kortum, R. (2005) Opt- 
ical Coherence Tomography: A Pilot Study of a New Imaging Technique for Non-Invasive Examination of Cervical Tissue. American Journal of Obstetrics \& Gynecology, 193, 83-88. https://doi.org/10.1016/j.ajog.2004.11.054

[177] Escobar, P.F., Rojas-Espaillat, L., Tisch, S., Enerson, C., Brainards, J., Smith, J., Tresser, N.J., Feldchtein, F.I., Rojas, L.B. and Belinson, J.L. (2006) Optical Coherence Tomography as a Diagnostic Aid to Visual Inspection and Colposcopy for Preinvasive and Invasive Cancer of the Uterine Cervix. International Journal of Gynecological Cancer, 16, 1815-1822. https://doi.org/10.1111/j.1525-1438.2006.00665.x

[178] Liu, Z., Belinson, S.E., Li, J., Yang, B., Wulan, N., Tresser, N.J., Wang, C., Mohr, M., Zhang, L., Zhou, Y., Weng, L., Wu, R. and Belinson, J.L. (2010) Diagostic Efficacy of Real-Time Optical Coherence Tomography in the Management of Preinvasive and Invasive Neoplasia of the Uterine Cervix. International Journal of Gynecological Cancer, 20, 283-287. https://doi.org/10.1111/IGC.0b013e3181cd1810

[179] Belinson, S.E., Ledford, K., Nabila, R., Rollins, A., Na, W., Wang, C., Xuan, R., Zhang, W., Zhu, Y., Tresser, N., Wu, R.F. and Belinson, J.L. (2013) Cervical Epithelial Brightness by Optical Coherence Tomography Can Determine Histological Grades of Cervical Intraepithelial Neoplasia. Journal of Lower Genital Tract Disease, 17, 160-166. https://doi.org/10.1097/LGT.0b013e31825d7bf0

[180] Gallwas, J., Turk, L., Friese, K. and Dannecker, C. (2010) Optical Coherence Tomography as a Non-Invasive Imaging Technique for Preinvasive and Invasive Neoplasia of the Uterine Cervix. Ultrasound in Obstetrics \& Gynecology, 36, 424-429. https://doi.org/10.1002/uog.7656

[181] Wulan, N., Rasool, N., Belinson, S.E., Wang, C., Rong, X., Zhang, W., Zhu, Y.S., Tresser, N.J., Mohr, M., Wu, R.F. and Belinson, J.L. (2010) Study of the Diagnostic Efficacy of Real-Time Optical Coherence Tomography as an Adjunct to Unaided Visual Inspection with Acetic Acid for the Diagnosis of Preinvasive and Invasive Neoplasia of the Uterine Cervix. International Journal of Gynecological Cancer, 20, 422-427. https://doi.org/10.1111/IGC.0b013e3181d09fbb

[182] Gallwas, J., Turk, L., Stepp, H., et al. (2011) Optical Coherence Tomography for the Diagnosis of Cervical Intraepithelial Neoplasia. Lasers in Surgery and Medicine, 43, 206-212. https://doi.org/10.1002/lsm.21030

[183] Lam, S., Standish, B., Baldwin, C., McWilliams, A., IeRiche, J., Gazdar, A., et al. (2008) In Vivo Optical Coherence Tomography Imaging of Preinvasive Bronchial Lesions. Clinical Cancer Research, 14, 2006-2011. https://doi.org/10.1158/1078-0432.CCR-07-4418

[184] MacAulay, C.E., Cox, D., Lane, P., Atkinson, E.N., Yamal, J.-M., Fradkin, L., Serachitopol, D., Lam, S., Pahlevaninezhad, H., Lee, A.M., Raizada, R., Miller, D., McAlpine, J., Ehlen, T., Finlayson, S., Kwon, J., Lee, M., Gutierrez, C., Mulla, Z., Schlosser, C., Castaneda, K., Castaneda, F. and Follen, M.(2016) Multi-Excitation, Multi-Emission Autofluorescence Imaging (AFI) for the In Vivo Identification of at Risk Cervical Tissue. Biomedical Optics, Paper JTh3A.3. https://doi.org/10.1364/CANCER.2016.JTh3A.3

[185] Barton, J.K., Guzman, F. and Tumlinson, A. (2004) Dual Modality Instrument for the Simultaneous Optical Coherence Tomography Imaging and Fluorescence Spectroscopy. Journal of Biomedical Optics, 9, 618-623. https://doi.org/10.1117/1.1695564

[186] Sung, K.B., Liang, C., Descour, M., Collier, T., Follen, M., Malpica, A. and Richards-Kortum, R. (2002) Near Real Time In Vivo Fiber Optic Confocal Microscopy: Sub-Cellular Structure Resolved. Journal of Microscopy, 207, 137-145. https://doi.org/10.1046/j.1365-2818.2002.01049.x 
[187] Drezek, R.A., Collier, T., Brookner, C.K., Malpica, A., Lotan, R., Richards-Kortum, R.R. and Follen, M. (2000) Laser Scanning Confocal Microscopy of Cervical Tissue before and after Application of Acetic Acid. American Journal of Obstetrics \& $G y^{-}$ necology, 182, 1135-1139. https://doi.org/10.1067/mob.2000.104844

[188] Collier, T., Shen, P., de Pradier, B., Sung, K., Richards-Kortum, R., Malpica, A. and Follen, M. (2000) Near Real Time Confocal Microscopy of Amelanotic Tissue: Dynamics of Aceto-Whitening Enable Nuclear Segmentation. Optics Express, 6, 40-48. https://doi.org/10.1364/OE.6.000040

[189] Clark, A., Collier, T., Lacy, A., Follen, M., Malpica, A., Gillenwater, A. and Richards-Kortum, R. (2002) Detection of Dysplasia with Near Real Time Confocal microscopy. Biomedical Sciences Instrumentation, 38, 393-398. PMID: 12085638.

[190] Sung, K.B., Liang, C., Descour, M., Collier, T., Follen, M. and Richards-Kortum, R. (2002) Fiber-Optic Confocal Reflectance Microscope with Miniature Objective for In Vivo Imaging of Human Tissues. IEEE Transactions on Biomedical Engineering, 49, 1168-1172. https://doi.org/10.1109/TBME.2002.803524

[191] Collier, T., Lacy, A., Richards-Kortum, R., Malpica, A. and Follen, M. (2002) Near Real Time Confocal Microscopy of Amelanotic Tissue: Detection of Dysplasia in EX Vivo Cervical Tissue. Academic Radiology, 9, 504-512. https://doi.org/10.1016/S1076-6332(03)80326-4

[192] Sung, K.B., Richards-Kortum, R., Follen, M., Malpica, A., Liang, C. and Descour, M.R. (2003) Fiber Optic Confocal Reflectance Microscopy: A New Real-Time Technique to View Nuclear Morphology in Cervical Squamous Epithelium in Vivo. Optics Express, 11, 3171-3181. https://doi.org/10.1364/OE.11.003171

[193] Sokolov, K., Aaron, J., Hsu, B., Nida, D., Gillenwater, A., Follen, M., MacAulay, C., Storthz, K.A., Korgel, B., Descour, M., Pasqualini, R., Arap, W., Lam, W. and Richards-Kortum, R. (2003) Optical Systems in Vivo Molecular Imaging of Cancer. Technology in Cancer Research \& Treatment, 2, 491-504. https://doi.org/10.1177/153303460300200602

[194] Collier, T., Arifler, D., Malpica, A., Follen, M. and Richards-Kortum, R. (2003) Determination of Epithelial Tissue Scattering Coefficient Using Confocal Microscopy. IEEE Journal of Quantum Electronics, 9, 307-313. https://doi.org/10.1109/JSTQE.2003.814413

[195] Carlson, K., Chidley, M., Sung, K., Descour, M., Gillenwater, A., Follen, M. and Richards-Kortum, R. (2005) In Vivo Fiber-Optic Confocal Reflectance Microscope with an Injection-Molded Plastic Miniature Objective Lens. Applied Optics, 44, 1792-1797. https://doi.org/10.1364/AO.44.001792

[196] Collier, T., Follen, M., Malpica, A. and Richards-Kortum, R. (2005) Sources of Scattering in Cervical Tissue: Determination of the Scattering Coefficient by Confocal Microscopy. Applied Optics, 44, 2072-2081. https://doi.org/10.1364/AO.44.002072

[197] Collier, T., Malpica, A., Guillaud, M., Follen, M. and Richards-Kortum, R. (2007) Real Time Reflectance Confocal Microscopy: Comparison of Two Dimensional Images and Three Dimensional Image Stacks for Detection of Cervical Precancer. Journal of Biomedical Optics, 12, Article ID: 024021. https://doi.org/10.1117/1.2717899

[198] Carlson, K., Pavlova, I., Collier, T., Descour, M., Follen, M. and Richards-Kortum, R. (2005) Confocal Microscopy: Imaging Cervical Precancerous Lesions. Gynecologic Oncology, 99, S84-S88. https://doi.org/10.1016/j.ygyno.2005.07.049

[199] Muldoon, T.J., Pierce, M.C., Nida, D.L., Williams, M.D., Gillenwater, A. and Richards-Kortum, R. (2007) Subcellular-Resolution Molecular Imaging within Living Tissue by Microendoscopy. Optics Express, 15, Article ID: 16413.

https://doi.org/10.1364/OE.15.016413 
[200] Pierce, M.C. and Richards-Kortum, R. (2010) Low-Cost Portable Optical Imaging Systems for Cancer Diagnosis. 2010 Annual International Conference of the IEEE Engineering in Medicine and Biology Society (EMBC), Buenos Aires, 31 August-4 September 2010, 1093-1096. https://doi.org/10.1109/IEMBS.2010.5627330

[201] Shin, D., Pierce, M.C., Gillenwater, A., Williams, M.D. and Richards-Kortum, R. (2010) A Fiber-Optic Fluorescence Microscopy Using a Consumer-Grade Digital Camera for In Vivo Cellular Imaging. PLoS ONE, 5, e11218. https://doi.org/10.1371/journal.pone.0011218

[202] El Hallani, S., Poh, C.F., MacAulay, C.E., Follen, M., Guillaud, M. and Lane, P. (2013) EX Vivo Confocal Imaging with Contrast Agents for the Detection of Oral Potentially Malignant Lesions. Oral Oncology, 49, 582-590. https://doi.org/10.1016/j.oraloncology.2013.01.009

[203] Schlosser, C.L., Bodenschatz, N., Lam, S.F., Lee, M., McAlpine, J.N., Miller, D.M., Van Niekerk, D.J.T., Follen, M., Guillaud, M., MacAulay, C.E. and Lane, P.M. (2016) Fluorescence Confocal Endomicroscopy of the Cervix: Pilot Study on the Potential and Limitations for Clinical Implementation. Journal of Biomedical Optics, 21, Article ID: 126011. https://doi.org/10.1117/1.JBO.21.12.126011

[204] Shreikhzadeh, F., Ward, R.K., Carraro, A., Chen, Z.Y., van Niekerk, D., Miller, D., Ehlen, T., MacAulay, C.E., Follen, M., Lane, P.M. and Guillaud, M. (2015) Quantification of Confocal Fluorescence Microscopy for the Detection of Cervical Intraepithelial Neoplasia. Biomedical Engineering, 14, 96.

https://doi.org/10.1186/s12938-015-0093-6

[205] Shreikhzadeh, F., Ward, R.K., Carraro, A., Chen, Z.Y., van Niekerk, D., Miller, D., Ehlen, T., MacAulay, C.E., Follen, M., Lane, P.M. and Guillaud, M. (2015) Confocal Fluorescence Microscopy for the Detection of Cervical Preneoplastic Lesions. Proceedings of SPIE Medical Imaging 2015: Digital Pathology, Orlando, 27 April 2015. https://doi.org/10.1117/12.2077268

[206] Bodenschatz, N., Lam, S., Carraro, A., Korbelik, J., Miller, D.M., McAlpine, J.N., et al. (2016) Diffuse Optical Microscopy for Quantification of Depth-Dependent Epithelial Backscattering in the Cervix. Journal of Biomedical Optics, 21, Article ID: 66001. https://doi.org/10.1117/1.JBO.21.6.066001

[207] Bodenschatz, N., Poh, C.F., Lam, S., Lane, P.M., Guillaud, M. and MacAulay, C.E. (2017) Dual-Mode Endomicroscopy for Detection of Epithelial Dysplasia in the Mouth: A Descriptive Pilot Study. Journal of Biomedical Optics, 22, 1. https://doi.org/10.1117/1.JBO.22.8.086005

[208] Cardenas-Turanzas, M., Follen, M., Benedet, J.L. and Cantor, S.B. (2005) See-and-Treat Strategy for the Diagnosis and Management of Cervical Squamous Intraepithelial Lesions. The Lancet Oncology, 6, 43-50. https://doi.org/10.1016/S1470-2045(04)01712-7

[209] Cantor, S.B., Mitchell, M.F., Tortolero-Luna, G., Bratka, C.S., Bodurka, D.C. and Richards-Kortum, R. (1998) Cost-Effectiveness Analysis of Diagnosis and Management of Cervical Squamous Intraepithelial Lesions. Obstetrics \& Gynecology, 91, 270-277. https://doi.org/10.1016/S0029-7844(97)00623-6

[210] Davies, K.R., Cantor, S.B., Cox, D.D. and Follen, M. (2015) An Alternative Approach for Estimating the Accuracy of Colposcopy in Detecting Cervical Precancer. PLoS $O N E$, 10, e0126573. https://doi.org/10.1371/journal.pone.0126573

[211] Nghiem, V.T., Davies, K.R., Beck, J.R., Follen, M., MacAulay, C., Guillaud, M. and Cantor, S.B. (2015) Economic Evaluation of DNA Ploidy Analysis versus Liquid-Based Cytology for Cervical Screening. British Journal of Cancer, 112, 1951-1957.

https://doi.org/10.1038/bjc.2015.95 
[212] Cantor, S.B., Sun, C.C., Tortolero-Luna, G., Richards-Kortum, R. and Follen, M. (1999) A Comparison of C/B Ratios from Studies Using Receiver Operating Characteristic Curve Analysis. Journal of Clinical Epidemiology, 52, 885-892. https://doi.org/10.1016/S0895-4356(99)00075-X

[213] Cantor, S.B., Levy, L.B., Cardenas-Turanzas, M., Basen-Engquist, K., Le, T., Beck, J.R. and Follen, M. (2006) Collecting Direct Non-Health-Care and Time Cost Data: Application Screening and Diagnosis of Cervical Cancer. Medical Decision Making, 26, 265-272. https://doi.org/10.1177/027298906288679

[214] Nghiem, V.T., Davies, K.R., Beck, J.R., Follen, M. and Cantor, S.B. (2016) Overtreatment and Cost-Effectiveness of the See-and-Treat Strategy for Managing Cervical Precancer. Cancer Epidemiology, Biomarkers, and Prevention, 25, 807-814. https://doi.org/10.1158/1055-9965.EPI-15-1044

[215] Swartz, R.J., Cox, D., Cantor, S.B., Davies, K. and Follen, M. (2006) Inverse Decision Theory: Characterizing Losses for a Decision Rule with Applications in Cervical Cancer Screening. Journal of the American Statistical Association, 101, 1-8.

https://doi.org/10.1198/016214505000000998

[216] Davies, K.R., Cox, D.D., Swartz, R.J., Cantor, S.B. and Follen, M. (2007) Inverse Decision Theory with Applications to Screening and Diagnosis of Cervical Intraepithelial Neoplasia. Gynecologic Oncology, 107, S187-S195.

https://doi.org/10.1016/j.ygyno.2007.07.053 